\title{
sciendo
}

\section{FOREST TRANSFORMATION URGENCY FOR TOPSOIL DIVERSITY OPTIMIZATION DURING ENVIRONMENTAL CHANGE}

\author{
PAVEl SAMEC ${ }^{1,2, *}$, MilOŠ ZAPLETAL ${ }^{2,3,4}$, MATĚJ HORÁČEK ${ }^{5}$ \\ ${ }^{1}$ Department of Geology and Pedology, Faculty of Forestry and Wood Technology, Mendel \\ University in Brno, Zemédělská 3, CZ-613 00 Brno, Czech Republic \\ ${ }^{2}$ Global Change Research Institute CAS, Belidla 986/4a, CZ-603 00 Brno, Czech Republic \\ ${ }^{3}$ Silesian University in Opava, Faculty of Philosophy and Science, Masarykova 37, \\ CZ-746 01 Opava, Czech Republic \\ ${ }^{4}$ Centre for Environment and Land Assessment - Ekotoxa, Otická 37, CZ-746 01 Opava, \\ Czech Republic \\ ${ }^{5}$ Department of Physical Geography and Geoecology, Faculty of Science, University of \\ Ostrava, Chittussiho 14, CZ-710 00 Ostrava, Czech Republic \\ *Corresponding authore-mail: psamec@post.cz.
}

Received: $16^{\text {th }}$ April 2020, Accepted: $8^{\text {th }}$ October 2020

\begin{abstract}
Combined effect of environmental change and management variability leads to reduced soil diversity in homogenous forest stands. On the other hand, forest soil diversity is maintained with rich tree species composition. In this study, focus has been put on deriving urgency to change forest tree species composition in order to increase soil diversity in biogeographic regions with uneven impact of environmental change. The relation of forest tree species and soil diversities was compared between the periods of dominant sulphur deposition (1985-1994) and the period of regional environmental change (2003-2012) in the Czech Republic (Central Europe; $78866 \mathrm{~km}^{2}$; 115-1602 m n.m.). Forest tree species and soil diversities were assessed using linear regression, discrimination analysis and geographically weighted regression including residue analysis. The effect of spatial differences of acid deposition on soil properties, though, decreased, still dependencies between the diversity of bedrock, soils and forest tree species increased significantly. Only $12.9 \%$ of forests in the territory of the CR have optimum tree species diversity. The total of $65.9 \%$ of forest require highly or moderately urgent transformation. An increase in spatial dependencies between soil and tree species diversities confirms the importance of site differentiation in forest transformation.
\end{abstract}

Keywords: acid deposition; forest restoration; biogeographical division; ecosystem diversity

\section{INTRODUCTION}

Combined operations of environmental change and inconstant forest management afflict ecosystem diversity unprecedently. Ecosystem diversity indicates landscape ability to adapt on environmental changes. A sufficient number of sustainably used forests can support 
Samec P., Zapletal M., Horáček M.: Forest transformation urgency for topsoil diversity optimization during environmental change

landscape adaptability more than intensively managed forests. Intensive forest management reduces ecosystem diversity by cultivating a small number of tree species and by homogenisation of soil properties (Podrázský et al., 2009), whereas sustainable management of close-to-nature forests does not reduce ecosystem diversity to a significant degree (Aubert et al., 2003). Environmental variability brings changes in all forest functions, so that even the effect of sufficient number of sustainably used forests is unstable. A direct correlation between environmental change and ecosystem diversity occurs when all ecosystems are able to adapt (Bellard et al., 2012). Relations between the environment variability and ecosystem diversity indicate whether the ecosystem adaptability can be ensured by reducing environmental load or via ecological restoration.

Ecosystem diversity consists of biodiversity (life form variety) and geodiversity (growth condition variety). There is certain feedback between biodiversity and geodiversity. Geodiversity conditions natural biodiversity, but biodiversity helps to increase geodiversity through intensified soil development (Ibañez \& Feoli, 2013). Soil development constantly changes the internal environment of terrestrial ecosystems. Intensified development of forest soils is provided by the tree-soil system (TSS). TSS is an open connection of plants, soil and microorganisms exchanging substances between one another and the surrounding environment (Hopkins et al., 2013). Forest internal environment variability as well as influence on the surrounding environment are subject to human activity. Human activity along with soil development affects the TSS performance. Human activity has a direct effect on trees and soil organic matter (Pretzsch et al., 2014). The relation of soil development and trees is based on the intensification in biochemical disintegration of mineral components, formation of organo-mineral complexes and blending of weathered rocks with organic matter. Soil development is manifested by mantle deepening and variations in organic matter content (Augusto et al., 2000). Subsequently, forest species composition changes in connection with the individual tree species dieback and regeneration cycles, episodic disturbances, and water and nutrient availability (Ponge \& Chevalier, 2006). Forest soil development is accelerated by weather disturbances both by relocating weathered rocks and incorporating organic matter into the soil body. Material relocation leads to the transformation of micro-scale landforms. The micro-scale landforms that have been broken down provide niches with various content of organic matter and moisture for trees (Legout et al., 2009). Disturbances and cyclical dieback of longest-living tree species allow for the outgrowing of more nutrient-demanding species, which is accompanied by an increase in the species richness (Modrý et al., 2004).

Joint participation of environmental change and human activity results in regulating or supressing natural changes in forest species composition. Forest regeneration is a triggering process of TSS changes. Natural forest regeneration most often occurs after disturbances or dieback of main tree storey. On the other hand, natural forest regeneration is significantly supressed by environmental pollution or dense herbivore population (Gill \& Beardall, 2001; Zapletal, 2006; Ponge \& Chevalier, 2006). The absence of natural forest regeneration or regeneration of undesired (invasive) species limit the transformation of forest composition to artificial regeneration. Artificial regeneration is, however, the fastest way to change forest composition in order to alleviate the impact of further changes in growth conditions (Ponge et al., 1998). Restoration of natural forest composition reinforces the feedback with soil, which supports successful spread of the subsequent generation, whereas trees on unsuitable sites are more sensitive to growth conditions variability (Seppälä et al., 2009). Successful forest regeneration is related to the way of optimising the relations between a tree and growth conditions. Even though natural forest regeneration consists in the growth of tree species with optimum relation to growth conditions, its exploitation as a model for artificial 
regeneration is limited under permanent loads (Mauer et al., 2018). Nevertheless, balanced relationship between tree-species and growth conditions is irreplaceable presumption for successful artificial regeneration including introduction of unnatural species.

The aim of this study is to derive transformation urgency in forest tree species composition from the discrepancy between the species and soil diversities in trans-regional units with different environmental effects. The comparison of trans-regional units makes it possible to simplify the influence of tree species on soil in order to assess the relations between the total biodiversity and soil diversity (De Deyn et al., 2008). Different levels of lost biodiversity and susceptibility to pollution are factors that most differentiate the forest resistance (Chapin III et al., 2000). Lower resistance of unnatural forests increases the threat of residual acidification after the pollution have dropped (Oulehle et al., 2011). Homogenous stands are associated with uniform topsoil horizons, while mixed forests with various topsoils (Valtera et al., 2013). Since heterogenous soils adapt to changes in external conditions better, the goal of TSS analysis was to assess the increase in dependency between tree species and soil diversities during periods of different environmental loads (Rejšek et al., 2010; Bellard et al., 2012). Variability in relations between TSS components is studied on the basis of changes in soil properties or direction within tree species composition. Variability in soil properties depending on changes in tree species composition points to the tree species impact effectiveness. The rate of dependency implies the impact of mixed forests on soil diversity (Chisholm et al., 2013). Changes in TSS resistance is identified comparing deviations in relations between forest and soil diversity. Sufficient forest resistance achieved by the transformation of tree species composition is detected from a decrease in suboptimal relations in TSS after pollution has decreased (Seppälä et al., 2009).

\section{MATERIAL AND METHODS}

\section{General approach}

Variability in relations between forest trees and soils was simplified to estimation of diversity in biogeographic regions of the Czech Republic (78 $866 \mathrm{~km}^{2}, 115-1602 \mathrm{~m}$ a. s. 1.) (Culek, 2007). Natural forestland of the Czech Republic exceeds $98 \%$ except high-mountain, rocky, or peat bog treeless areas (Neuhäuslová et al., 1998). Contemporary forestland is $34 \%$ of the country. Natural tree composition included mainly European beech (Fagus sylvatica) (40\%), oaks (Quercus sp.) (18\%), European silver fir (Abies alba) (16\%), Norway spruce (Picea abies) (15\%), and Scots pine (Pinus sylvestris) (3\%) (Šindelár, 1995), whereas contemporary forest composition after inventory in 2011-2014 contained predominantly $44 \%$ of Norway spruce, almost $10 \%$ of Scots pine, more than $10 \%$ of European beech, and $8 \%$ of oaks (Kučera, 2016).

Components of forest ecosystem diversity were compared between the periods of dominant industrial load caused by sulphur deposition (1985-1994) and a regional environmental change (2003-2012). Environmental loads afflict forests both directly and by highlighting sensitivity to periodically occurring harmful agents (Schröder et al., 2015). The compared periods were divided by desulphurisation of large industrial pollution sources and by an increase in the frequency of droughts alternating with floods. Durations of both periods were limited by ten-year intervals corresponding with medium-term forestry planning (Tomášková, 2004). In 1985-1994, emission-ecological disaster due to dominant $\mathrm{SO}_{2}$ deposition culminated in the CR during more frequent hard winters. Year 1994 was final occurence of exceeded critical sulphur dry deposition levels, although desulphurisation in industry was completed upto in 1998. The period 2003-2012 has begun by extraordinary dry year, which initiated increasing frequency of warmer years with highlighting impacts of 
Samec P., Zapletal M., Horáček M.: Forest transformation urgency for topsoil diversity optimization during environmental change

nitrogen deposition (Luterbacher et al., 2004; Galloway et al., 2008; Büntgen et al., 2011). $\mathrm{SO}_{2}$ and cold weather extremes during 1985-1994 caused dieback of exposed mountain forests, while warming and nitrogen deposition damaged submountain forests more (Schröder et al., 2015). Prior to the desulphurisation, total potential acid deposition (TPAD) reached $50000 \mathrm{~mol}^{+} /$hectare per year, out of which sulphur deposition amounted to $26000 \mathrm{~mol}^{+} /$hectare per year. The TPAD decreased after desulphurisation to $1100-$ $4500 \mathrm{~mol}^{+} /$hectare per year, there out sulphur deposition decreased to $200-1800 \mathrm{~mol}^{+} /$hectare per year. Difference between a slight TPAD decrease and a significant decline in sulphur deposition was caused by an episodic increase in nitrogen deposition. Average sulphur deposition decreased from $1000 \mathrm{~mol}^{+} /$hectare per year to $630 \mathrm{~mol}^{+} /$hectare per year, while nitrogen deposition decreased from $1700 \mathrm{~mol}^{+} / \mathrm{hectare}$ per year to mere $1300 \mathrm{~mol}^{+} /$hectare per year (Zapletal, 2006).

The assessment of variability in relations between forest trees and soils consisted in survey, geographical, and comparison analyses. The purpose of the comparison analysis was to verify environmental preconditions for TSS development. Preconditions for modelling were verified by indicating declining influence of environmental load and growing influence of trees on soil properties, as TSS development only becomes efficient when the influence of environmental load declines (Langan \& Wilson, 1994). The purpose of the geographical analysis was to assess the importance of TSS spatial dependencies. The comparison analysis was focused on deriving the urgency of forest composition transformation from abnormalities in forest tree dependencies with soil diversity and geodiversity.

\section{Data}

Compared data included TPAD matrices and ecosystem diversity components. The TPAD was interpolated at $1 \times 1 \mathrm{~km}$ grid, while ecosystem diversity components were vectorized. Data was combined through intersections between rasters and vectors.

\section{Acid deposition}

TPAD was characterised as a sum of total sulphur and nitrogen depositions according to EMEP-LRTAP (Erisman et al., 2005). The model of acid deposition was assembled from 16266 cells of which every one was covered by forest over $70 \%$ (Samec et al., 2016). The period of industrial load was characterised on the basis of the TPAD model in 1994, while the period of environmental change was characterised by the year 2003. Average TPAD in 1994 amounted to $3257 \mathrm{~mol}^{+} /$hectare per year in the interval $1512-6742 \mathrm{~mol}^{+} /$hectare per year. In 2003 average TPAD decreased to $1780 \mathrm{~mol}^{+} /$hectare per year within the range $786-$ $4360 \mathrm{~mol}^{+} /$hectare per year. Acid deposition in 1994 reached a wide interval from low to very high values with the prevailing value representation in the interval $2000-4000 \mathrm{~mol}^{+} /$hectare $^{2}$ per year. In 2003 the TPAD interval narrowed to low up to middle values with the highest representation of values $1500-2000 \mathrm{~mol}^{+} /$hectares per year.

\section{Tree-soil system}

TSS was characterised by means of point and polygon geospatial data. Spatial characteristics included biogeographic regions, tree species composition and soil data. Biogeographic regions (bioregions) are basic units of individual division of living communities. In the Czech Republic, there are 91 bioregions within two provinces and four subprovinces. Central European Province includes Hercynian Subprovince, Polonian Subprovince, and West Carpathian Subprovince (Fig. 1) (Culek, 2007). Based on the data of the Uniform information system on the environment of the Ministry of the Environment of the Czech Republic, polygons of bioregions are divided into 9187 subpolygons of 
366 ecosystem types (Culek \& Grulich, 2009). The ecosystem types were defined using combination of eight altitudinal zones, 18 landform types, and 31 bedrock types.

Fig. 1: Biogeographic division of regions and subprovinces within the Czech Republic (adapted according to Culek, 2007).

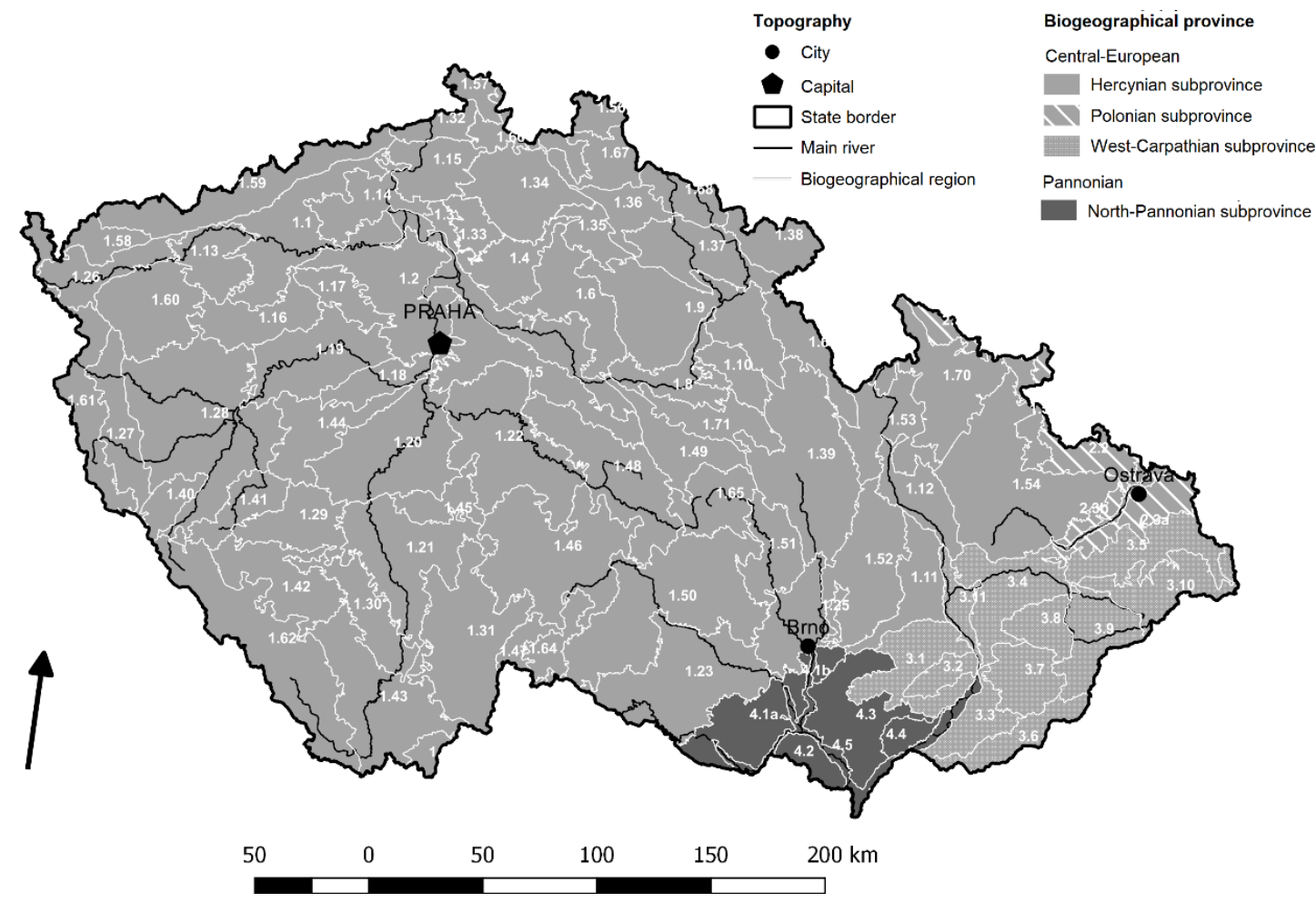

\section{Forest tree species}

Tree species data were simplified to calculation of domestic species or aggregated taxon proportions from forest management plans (FMP) (Culek, 2007). Data on the tree species proportions were included to the bioregional database. Out of the total number of 200 woody species identified in the territory of the Czech Republic, 78 of them are trees, 85 are bushes and shrubs, and 26 are subshrubs. Forest management deals with 40 domestic species and 42 aggregated taxons. Tree species proportion $(Z)$ was derived as a percentage from the area sums of all forest stands within a bioregion at the FMP database of the Information and Data Centre of the Forest Management Institute (IDC FMI) Brandýs nad Labem.

Between the periods of interest, there was a slight decrease in conifer proportion, but at the same time an increase in deciduous trees proportion. In the period of 1985-1994, the percentage of coniferous trees amounted to $77.5 \%$, whereas the percentage of deciduous trees was $22.5 \%$. Norway spruce $(P$. abies) was represented by almost $55.4 \%$, and pines (Pinus sp.) were represented by almost $18.0 \%$. The proportion of silver fir (A. alba) was $<1 \%$, and of European larch (Larix decidua) it was $<3.3 \%$. As for deciduous trees, the highest proportion was that of European beech (F. sylvatica) $(5.8 \%)$, oaks $(Q$. sp.) $(6.0 \%)$, birch (Betula sp.), common hornbeam (Carpinus betulus) (1.3\%), and alder (Alnus sp.) $(1.5 \%)$. Amount of coniferous and deciduous forest stands in the sample point field was similar to proportion in bioregions according to FMPs but the total shares of spruce $(60.1 \%)$, 
Samec P., Zapletal M., Horáček M.: Forest transformation urgency for topsoil diversity optimization during environmental change

beech $(12.1 \%)$ and oaks $(6.7 \%)$ were higher. The total conifer proportion slightly decreased in the period of $2003-2012$ to $73.1 \%$, while the deciduous trees proportion increased to $26.9 \%$. The percentage of sampled spruce $(60.9 \%)$, beech $(13.1 \%)$ and oak $(8,6 \%)$ forest stand remained higher, while the percentage of fir and other deciduous trees was $<1 \%$ (Fig. 2).

Fig. 2: Comparison of tree species (see Table 3) proportion (\%) in forests of the Czech Republic and in a pit point field during the period of dominant industrial load (a) or environmental change (b)

a) Period 1985-1994

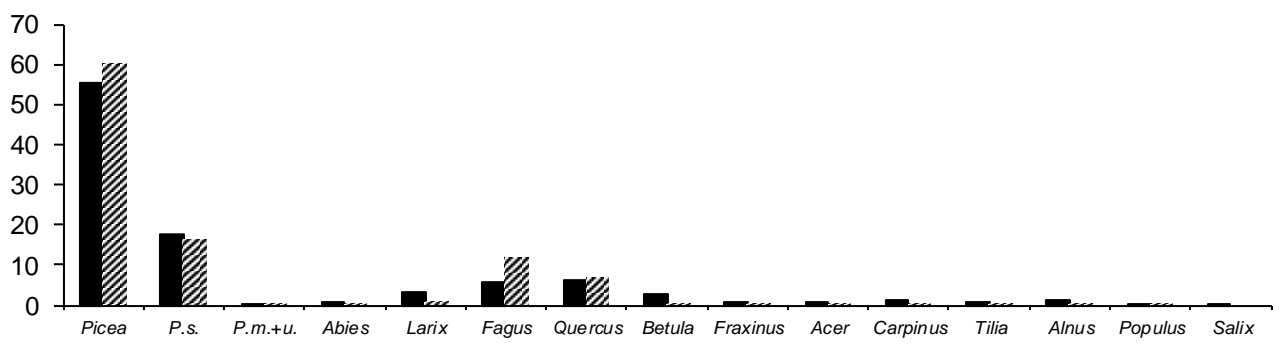

b) Period 2003-2012

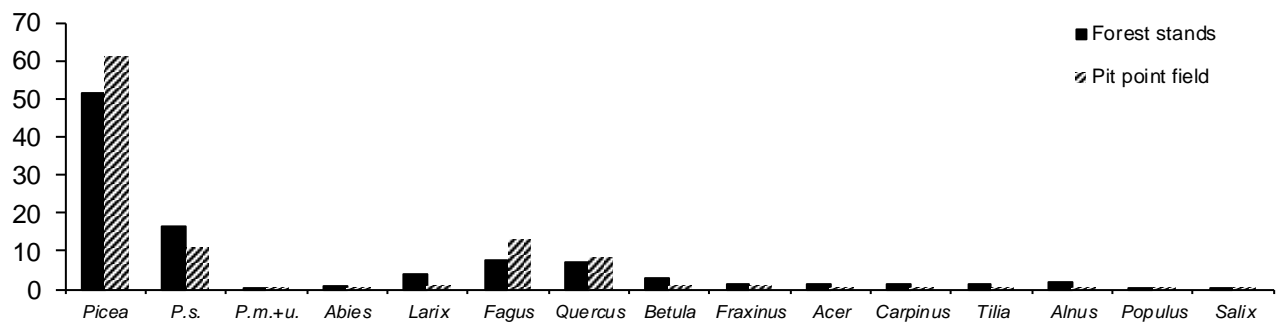

\section{Forest soil}

Soil data were obtained from polygons of bedrock-geomorphological bodies (BGMBs) and forest soil associations, and from a pilot survey pit point field. The polygons provided category variables of spatial soil units, while the point field provided the values of qualitative soil properties. A soil association is a repeatable matrix arrangement of the main soil unit and areas of accompanying or complementary units (Sedláček et al., 2009). Forest soil associations are occurrences of soil associations under forest cover. In the territory of the Czech Republic, there are 55 soil associations and forests cover 53 of them. Six associations occur entirely in forests. Associations of Vertisols and Gleyic Chernozems to Fluvisols occur solely on agricultural land, while associations of Histosols, Gleysols and a majority of Podzols only occur in forests (Samec et al., 2018). Polygons of forest soil associations were derived from the overlay between generalized physical geographical predictors and edaphic categories of forest types in the forest development regional plan (FDRP) database according to IDC FMI. The BGMB polygons were defined by the overlays between the bedrock and landform types in the database of ecosystem types (Culek \& Grulich, 2009).

The point field of qualitative soil properties was composed of 10940 pits of sampled forest soil associations with differentiated profile genetic horizons in the FDRP database. Soil units 
were characterised according to WRB-ISSS-ISRIC (Schad et al., 2014). Horizons were characterized through macroscopic features of soil body in relation with the external or internal environment of the ecosystem. The external environment affects mainly topsoil horizons, whereas the internal environment constitutes diagnostic horizons. The topsoil horizons were characterised by decomposed litter $(\mathrm{H})$ or a mixture of crushed and decomposed litter $(\mathrm{F}+\mathrm{H})$ of the surface humus and in the case of their absence by organo-mineral A-horizons on mineral substrates or surface peat horizons on organogenic substrates. Diagnostic horizons were characterised by either metamorphic B-horizons or soil-forming substrate. Soil properties were divided into particle-related and pedochemical. The particle size was represented by the share of clay particles $(<0.002 \mathrm{~mm})$ determined either from the point of sedimentography up to the year 2008, or subsequently from the point of granulometry (Stępień et al., 2015). Pedochemical properties were divided into physical-chemical and chemical. Physical-chemical properties were represented by soil $\mathrm{pH}$ determined in an acidimetric way, cation exchange capacity (CEC) and base saturation (BS). Exchange cations were identified by means of the extraction of $\mathrm{CH}_{3} \mathrm{COONH}_{4}$ up to the year 2000 (Blakemore \& Metson, 1960) and subsequently by extraction in $\mathrm{BaCl}_{2}$ (Vanmechelen et al., 1997). CEC and BS were calculated using the aggregation method (White, 1987).

Chemical properties included organic substances and mineral nutrients. Organic carbon $\left(\mathrm{C}_{\text {org }}\right)$ was determined by an oxidation-titrimetry way up to the year 2000 and subsequently by instrumental mineralization (Bremner, 1996). Total nitrogen $\left(\mathrm{N}_{\text {tot }}\right)$ was established by the Kjeldahl method by the year 2000 (Houba et al., 1989), subsequently by means of instrumental modification of the Dumas method (Buckee, 1994). The contents of mineral nutrients $\mathrm{Fe}_{2} \mathrm{O}_{3}, \mathrm{Al}_{2} \mathrm{O}_{3}, \mathrm{CaO}, \mathrm{MgO}, \mathrm{K}_{2} \mathrm{O}$ and $\mathrm{P}_{2} \mathrm{O}_{5}$ were determined by extraction in aqua regia (Houba et al., 1993).

The point field included all soil groups, however, only 16 of them were sampled in the period of 1985-1994 three out of which were only recorded under one tree species. In the period of 2003-2012, only two groups were sampled under one tree species. In 1985-1994 only three soil groups Cambisols, Podzols and Stagnosols were sampled under a majority of tree species, while in 2003-2012, a majority of tree species were identified on Fluvisols, Cambisols, Stagnosols, and Gleysols. Cambisols (60.2\%), Haplic Podzols (8.9\%), Stagnosols (8.3\%), Entic Podzols (6.7 \%), Retisols (3,3\%), Haplic Leptosols (2.5\%), and Gleysols (2.3\%) comprise over $90 \%$ of sampled pits (Fig. 3 ).

Fig. 3: Comparison of forest soil associations (\%) within the Czech Republic and in a pit point field during the period of dominant industrial load (1985-1994) and environmental change (2003-2012)

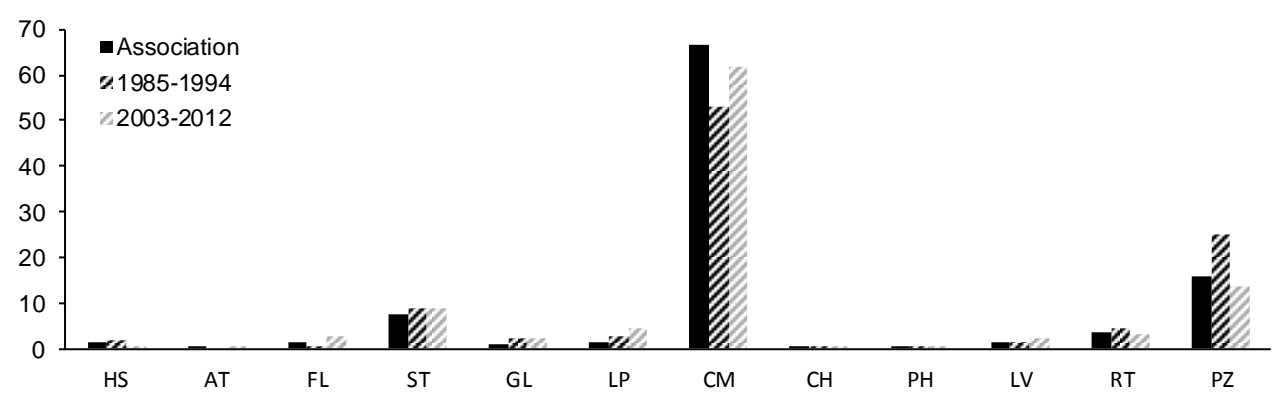


Samec P., Zapletal M., Horáček M.: Forest transformation urgency for topsoil diversity optimization during environmental change

However, the representation of soil groups differed during individual sampling periods. In the period of industrial load, a majority of pits were sampled in Cambisols (52.9\%), Haplic Podzols (16.5\%), Stagnosols (8.7\%), Entic Podzols (8.6\%) and Retisols (4.6\%). Unlike this, a majority of pits sampled in the period of a recent environmental change comprised seven soil groups starting with Cambisols (61.8\%), Stagnosols $(8.3 \%)$, Haplic $(7.3 \%)$ or Entic Podzols $(6.3 \%)$ to less represented Retisols (under 3\%), Leptosols $(2.7 \%)$ and Luvisols $(2.3 \%)$.

\section{Statistical analysis}

\section{Exploratory data analysis}

Exploratory data analysis was focused on the verification of statistical assumptions from the spatial modelling and environmental assumptions of the acid deposition reduction within the CR. The verification of statistical assumptions included the comparison of selected representants, normality tests and regression diagnostics. Representative values were used to compare the number of trees and soil properties between the periods of different environmental loads. The properties of forest ecosystems helped to verify the connections at TSS and to comparison of similarity in distribution of soil pits among bioregions. Normality tests were used to select suitable data standardizations, regression diagnostics was used to clarify non-linearities of geographical models (Zar, 1994). Regression diagnostics was carried out by means of Scott Test for Multicollinearity (SC), Cook-Weisberg Test for Heteroskedasticity (C-W), and Wald Autocorrelation Test (Wa) (Meloun et al., 2002). Environmental assumptions were verified through linear regressions between the components of acid deposition and topsoil properties at $P<0.05$. The decrease in the dependence between the periods 1985-1994 and 2003-2012 pointed to an increasing influence of the internal stand structure on humus (Schröder et al., 2015).

The verification of the similarity in the soil pits arrangement served to assess the level of sampling frequency homogeneity. Similar sampling frequency in various bioregions pointed to the reliability in estimation of soil diversity difference (Faddy \& Smith, 2011). Homogeneity of sampling frequency was identified by means of an inferential quadrant test. The quadrant test consists in the comparison of the average number of sampled pits in artificially defined cells. The cell size $4 \times 4 \mathrm{~km}$ was established in such a way that the average pit frequency was $>1.5$.

The verification of the tree-soil connection was carried out using a discrimination analysis (DA) on the soil properties separability size in point field of sampled trees characterised by a most represented tree species in the main layer. Separability was compared between humus and B-horizon properties in individual periods of environmental change. The comparison of separability indicated whether soil properties were rather constituted by the forest tree species composition or by rocks (Augusto et al., 2000).

A subset of statistically similar dispersion of values was selected from among soil properties. The selection was performed by a series from multivariate exploratory procedures of the principal component analysis (PCA) and the intersection of the factor analysis (FA) and the cluster analysis (CLU). Soil properties were structured by units of determination and physical character into groups of particle size, physical and chemical properties, and chemical properties. PCA identified dissimilar covariances in sets of variables with identical units (Kooch et al., 2008). A single variable with the highest influential component was selected among variables with similar covariances. Factor loadings including $>90 \%$ were used to set the selection of potentially correlating properties from various sets using FA. FA was specified by means of CLU to a subset of properties with significant value similarity only with other sets (Samec et al., 2016). 


\section{Geographical analysis}

Changes in the soil properties diversity in connection with the change in tree species proportion was assessed using the spatial variability comparison of the dependence proximity and correlation between the differentially loaded periods. Geographical analysis included the approximation and assessment of spatial dependences between the TSS components. The assessment was divided into the comparison of geographically weighted and global models and analysis of residues. The comparison of models was focused on evaluation of differences among tree relations with humus and soil environment. The analysis of residues was used to derivation of urgency to change tree species composition. Spatial dependence was modelled through geographically weighted regression (GWR). GWR estimated locally variable parameters in relationships between trees and environment at coherent bioregions. Number of coherent bioregions was limited by the least local statistical significance suggesting interaction level (Fotheringham et al., 2002).

The diversity of TSS components was expressed through Shannon-Wiener $\left(H^{\prime}\right)$ diversity index (Kennedy \& Smith, 1998). Calculation of $H^{\prime}$-index was adapted either to estimation on TSS component variety proportion, or to frequencies of value intervals from topsoil properties similar selections. The estimation of TSS component proportion variety was derived as:

$$
H^{\prime}=-\sum\left(\frac{A_{n}}{A}\right) \cdot \log _{2}\left(\frac{A_{n}}{A}\right),
$$

where $A_{n}$ is a TSS component type area within a bioregion and $\mathrm{A}$ is sum of areas from all types of selected TSS component within a bioregion. The tree species proportion, forest soil associations and BGMBs was the basis for deriving $\beta$-diversity of TSS components (Samec et al., 2018). The numbers of topsoil property value classes served as a basis for expressing surface humus chemical diversity $\left(H^{\prime}{ }_{\mathrm{hc}}\right)$ :

$$
H_{\mathrm{hc}}^{\prime}=-\sum\left(\frac{g_{k}}{g}\right) \cdot \log _{2}\left(\frac{g_{k}}{g}\right),
$$

where $g_{k}$ is a number of pits within one class of the selected soil property values in a bioregion and $g$ is total number of pits.

A linear combination of localized $H^{\prime}{ }_{k}$-indexes from the selected humus properties was compared with tree, soil association or bedrock $\beta$-diversities through GWR:

$Y_{m}=\beta_{m 0}+\sum_{k=1}^{q} \beta_{m k} \cdot H_{m k}^{\prime}+\epsilon_{m}$

where $Y_{m}$ is a dependent variable at the place $m, p$ is a number of independent variables, $k$ is the order of independent variables, $H_{m k}^{\prime}$ is the value of $k$-th independent variable of soil property diversity at the place $m, \beta_{m 0}$ is an intercept parameter at the place $m, \beta_{m k}$ is a local guideline of the function of $k$-th independent variable, and $\epsilon_{m}$ is a casual error at the place $m$ (Gollini et al., 2015).

\section{Comparison analysis}

The transformation urgency of the forest tree species composition was defined by comparisons between tree species proportion and soil environment geographically weighted models. The comparison was conducted by the overlay of model standardized residues. 
Samec P., Zapletal M., Horáček M.: Forest transformation urgency for topsoil diversity optimization during environmental change

The residues $(e)$ were derived from the differences of observed $(Y)$ and modelled $(\bar{Y})$ dependent variables of forest ecosystem properties:

$e_{m}=Y_{m}-\hat{Y}_{m}$

Standardization was based on the evaluation of conformities or nonconformities in optimal and suboptimal residues on a qualitative scale from fulfilled to highly urgent forest transformation. The urgency was detected in bioregions where nonconformities occurred in optimal and suboptimal values of residues. The residues of forest tree species diversity (FTSD) and soil environment were evaluated reversely. A higher observed FTSD $H^{\prime}$-index than the modelled one was identified as optimal, while a lower observed $H^{\prime}$-index as suboptimal since higher observed diversity stands for sufficient variety of forest tree species diversity for a wider interval of humus characteristics (Valtera et al., 2013). On the other hand, higher observed $H^{\prime}$-index of soil environment than the modelled one was identified as suboptimal and a lower one as optimal since geodiversity naturally increases soil diversity (Phillips \& Marion, 2004).

\section{Results}

\section{Environmental assumptions}

Acid deposition decrease in the period of 1985-2012 facilitated stronger relations between soil properties and tree species via differentiation. Spatial differentiation manifested itself by increased differences between regions, whereas time differentiation manifested itself by increased dispersion in soil properties values. Roughly regular arrangement among soil pits complied with statistical assumption of sampling homogeneity for equally probable variability estimation of relations at TSS in all bioregions. Sampling frequency is directly proportional to forestland $\left(R^{2}=0.56\right)$. Almost $99.6 \%$ of cells of a designed grid included a larger or smaller forest area. Average grid forestland was $32.9 \%$, in the range between $0.0001 \%$ and $100 \% .16 .3 \%$ of cells remained unsampled. Sampling density reached $0.11 \mathrm{pits} / \mathrm{km}^{2}$ in the period of $1985-1994$ and then in the period of 2003-2012, it rose to 0.4 pits $/ \mathrm{km}^{2}$. The range of the dispersion-average relation between 0 and 0.0356 indicates that the pit arrangement appears to be regular in the grid with random variations concentrated in flat bioregions from the North Pannonian to Polonian Subprovince or scattered in depressions of the Hercynian Subprovince.

Spatial differentiation consists in unequal soil properties values dispersion. The dispersion differs most significantly between the Central European Province and the Pannonian Province. The Central European Province differs in greater significance of particle size fractions and physical-chemical characteristics and, by contrast, a lower number of chemical properties important for the forest soil differentiation. More significant differentiation of coarse-grained fractions rather than clay is identified in the territory of the Central European Province. On the other hand, in Pannonia, similarly important differentiation is associated with both sand and silt as well as clay. Minor particle size differentiation related to higher differentiation of chemical characteristics. A relation between the differentiation of physical-chemical properties and chemical properties is proportional only regionally. Surface humus in the territory of the Central European Province is less physically and chemically differentiated than that in Pannonia. Small differentiation of humus physical and chemical properties is related to smaller differentiation in soil mineral horizon chemical properties. However, in Pannonia, higher humus differentiation reflects higher 
differentiation of mineral horizons. The Central European Province is characterised by similarly differentiated $\mathrm{pH}$ and base saturation of mineral horizons, whereas in Pannonia, important physical-chemical differentiation is only that of BS. When comparing the two provinces, humus chemical properties are more detailed than physical-chemical properties. The content of $\mathrm{C}_{\text {org }}, \mathrm{Al}_{2} \mathrm{O}_{3}$ and $\mathrm{CaO}$ in the Central European Province is significantly differentiated and in Pannonia the content of $\mathrm{MgO}$ is more differentiated than that $\mathrm{CaO}$. The differentiation of chemical properties of mineral horizons in the Central European Province is limited to $\mathrm{Al}_{2} \mathrm{O}_{3}$ and $\mathrm{CaO}$, while in Pannonia these are accompanied by the contents of $\mathrm{C}_{\text {org }}$ and $\mathrm{P}_{2} \mathrm{O}_{5}$. Soil $\mathrm{pH}, \mathrm{BS}, \mathrm{C}_{\text {org }}, \mathrm{Al}_{2} \mathrm{O}_{3}, \mathrm{CaO}$ and $\mathrm{MgO}$ are greatly differentiated properties of surface humus in all the bioregions of the Czech Republic. Forest soils are characterised by differentiated particle size, $\mathrm{pH} / \mathrm{H}_{2} \mathrm{O}, \mathrm{BS}, \mathrm{C}_{\text {org }}, \mathrm{Al}_{2} \mathrm{O}_{3}, \mathrm{CaO}, \mathrm{MgO}$ and $\mathrm{P}_{2} \mathrm{O}_{5}$ (Tab. 1).

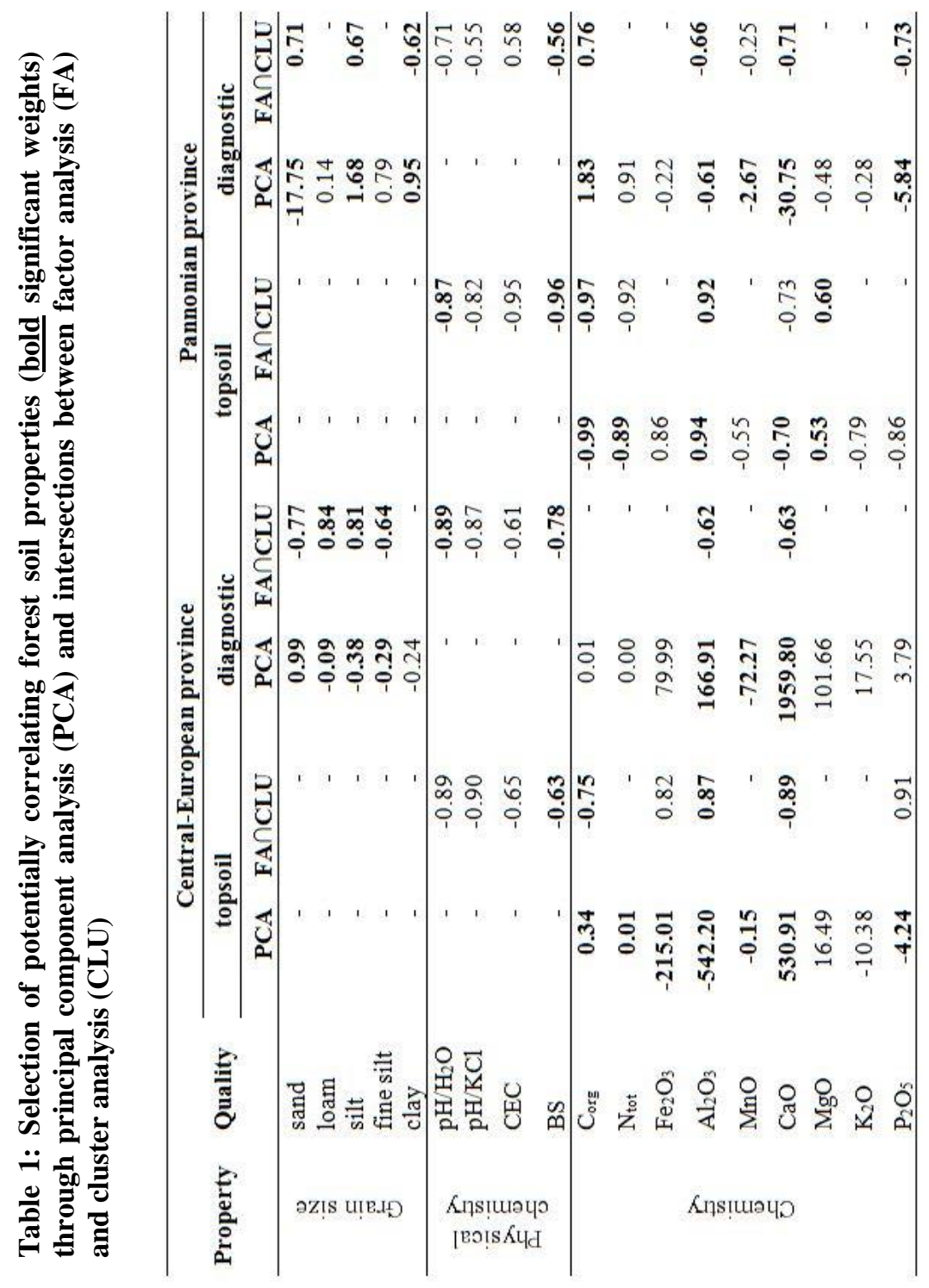


Samec P., Zapletal M., Horáček M.: Forest transformation urgency for topsoil diversity optimization during environmental change

Time differentiation consisted in concurrent value changes and in the increasing of soil properties intervals. The increase in the topsoil values was mostly accompanied also by their greater variance. Between the periods of 1985-1994 and 2003-2012, there was an increase in the values of humus $\mathrm{pH}, \mathrm{BS}, \mathrm{C}_{\text {org }}, \mathrm{N}_{\text {tot }}, \mathrm{CaO}$ and $\mathrm{P}_{2} \mathrm{O}_{5}$. At the same time, there was a decrease in the values of cation exchange capacity, $\mathrm{Al}_{2} \mathrm{O}_{3}$ and $\mathrm{MgO}$, but the variance declined only in the case of CEC and total aluminium. Only the changes in the $\mathrm{BS}$ and $\mathrm{CaO}$ content were accompanied by the preservation of a similar proportional value interval representation. Average soil pH increased from $4.05 \pm 0.59$ to $4.33 \pm 0.68$, soil $\mathrm{BS}$ increased from $27.34 \pm 21.64 \%$ to $35.83 \pm 26.80 \%$, and $\mathrm{CaO}$ content from $2.84 \pm 7.35 \mathrm{~g} / \mathrm{kg}$ to $3.13 \pm 10.16 \mathrm{~g} / \mathrm{kg}$. The carbon content increased from $11.84 \pm 10.62 \%$ to $14.37 \pm 12.52 \%$ along with the proportion of mean to very high values related to $82.30 \%$ of pits. The nitrogen content increased from $0.62 \pm 0,51 \%$ to $0.66 \pm 0.55 \%$, while the representation of very low to low values decreased and the representation of mean and high values related to $>71 \%$ pits increased. The content of total phosphorus increased from $0.99 \pm 0.59 \mathrm{~g} / \mathrm{kg}$ to $1.10 \pm 0.92 \mathrm{~g} / \mathrm{kg}$ with equal proportion of very low and mean values related to almost $97.2 \%$ probes. There was a decrease in $\mathrm{Al}_{2} \mathrm{O}_{3}$ from $24.51 \pm 12.66 \mathrm{~g} / \mathrm{kg}$ to $14.99 \pm 11.10 \mathrm{~g} / \mathrm{kg}$, along with a decrease in the representation of very high values from $74.7 \%$ to $34.2 \%$, but an increase in the representation of low to high values. The highest increase in the frequency occurred in the interval of high values from $18.4 \%$ to $39.6 \%$. There was a decrease in $\mathrm{MgO}$ content from $3.87 \pm 3.62 \mathrm{~g} / \mathrm{kg}$ to $2.65 \pm 4.88 \mathrm{~g} / \mathrm{kg}$. In this case, there was a decrease in the differences between the proportion of individual value intervals (Fig. 4).

A decrease in acid deposition highlighted the differentiation of topsoil properties along the borderline of bedrock types. Minor geodiversity is predisposition to higher TPAD and vice versa. An increase in the dependence between geodiversity and TPAD caused non-compliance between increasing or decreasing soil properties values. A decrease in acid deposition was accompanied by increased dependence of humus $\mathrm{CEC}, \mathrm{C}_{\mathrm{org}}, \mathrm{N}_{\text {tot }}, \mathrm{Al}_{2} \mathrm{O}_{3}$, and $\mathrm{CaO}$. A decrease in the dependence highlighted the differentiations of soil $\mathrm{pH}, \mathrm{BS}, \mathrm{MgO}$, and $\mathrm{P}_{2} \mathrm{O}_{5}$. Statistically significant dependences of content were those of $\mathrm{C}_{\text {org }}, \mathrm{N}_{\text {tot }}$, and $\mathrm{Al}_{2} \mathrm{O}_{3}$ and despite a decrease statistically important remained the $\mathrm{MgO}$ dependence (Tab. 2). Increasing dependencies of decreasing CEC values, and $\mathrm{Al}_{2} \mathrm{O}_{3}$ or $\mathrm{MgO}$ contents were inversely proportional to TPAD. The effect of decreasing acid deposition on growing $\mathrm{CaO}$ content was also inversely proportional, namely as a result of a slight increase in the importance of nitrogen deposition. During an environmental change, growing $\mathrm{C}_{\text {org }}$ and $\mathrm{N}_{\text {tot }}$ contents became statistically importantly directly dependent on TPAD due to sensitivity to sulphur deposition. 
Fig. 4: Value interval proportion (\%) of correlating properties at forest topsoil horizons during the period of dominant industrial load (a) and environmental change (b)

a) Period 1985-1994
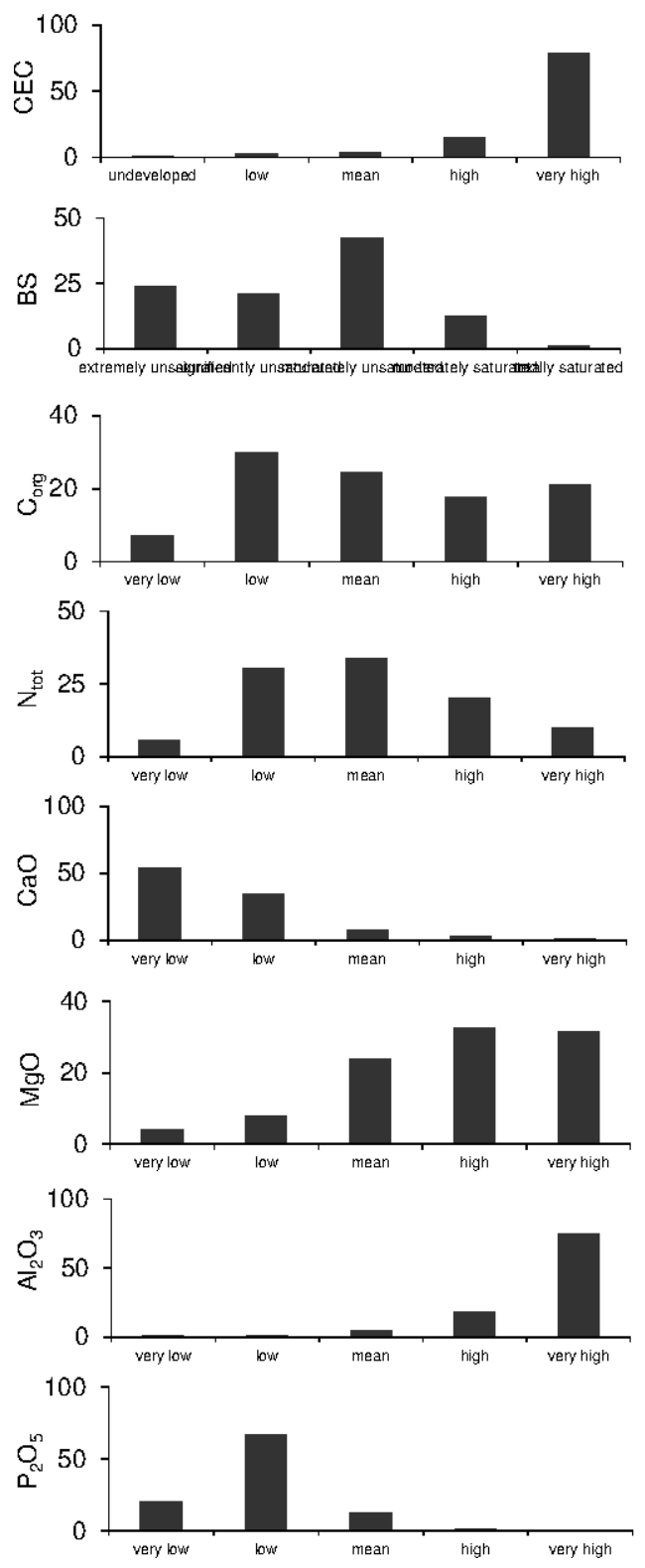

b) Period 2003-2012
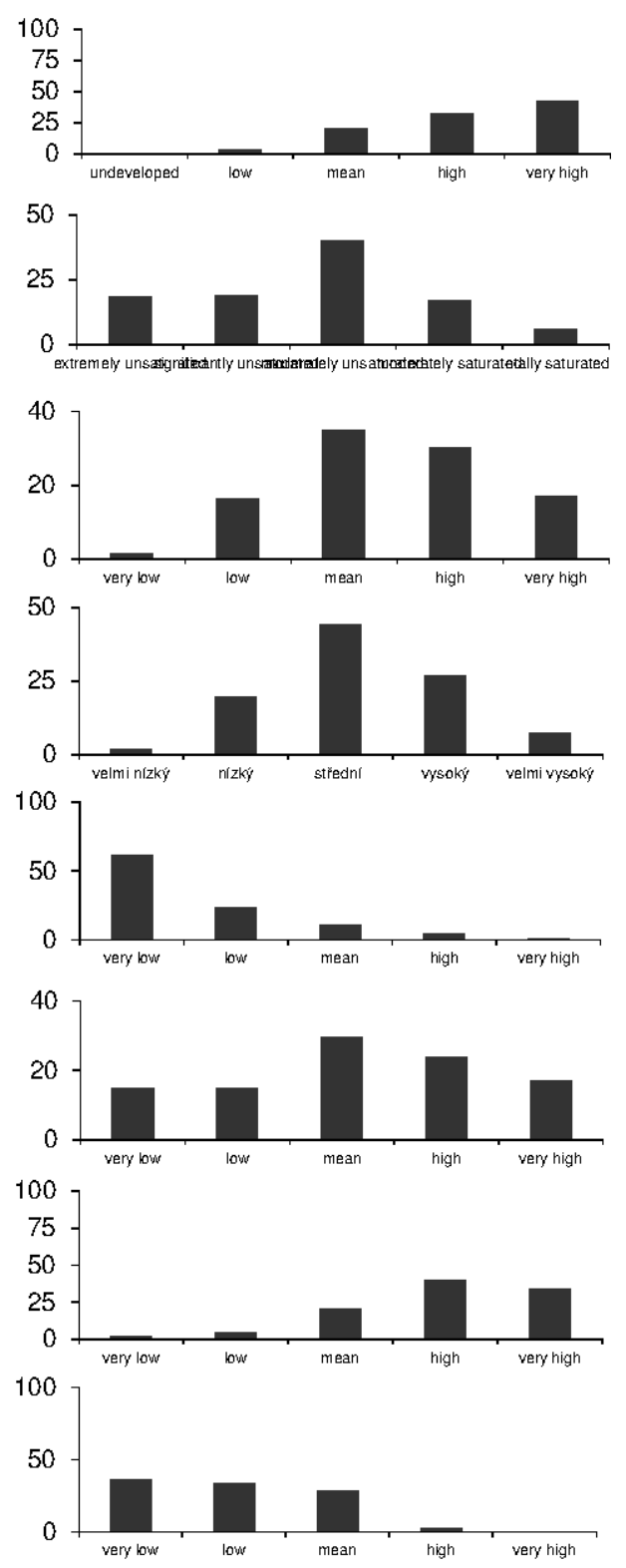


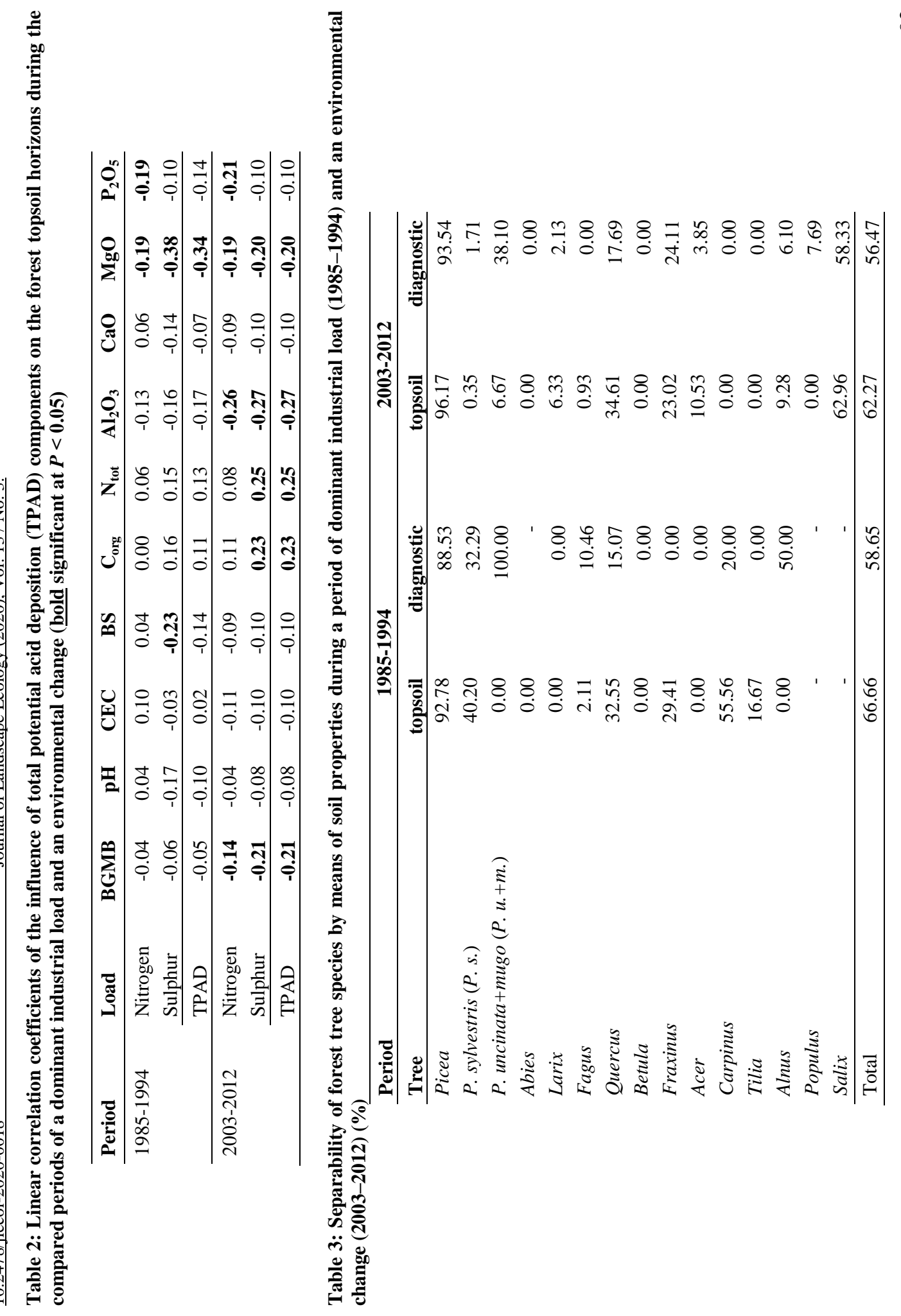


Trees influence topsoil chemical properties more significantly than those of diagnostic horizons. The discrimination of the individual tree species influence on soil properties during an environmental change decreased from $66.7 \%$ to $62.3 \%$ on average. Norway spruce maintains the most reliable discrimination of soil properties $>90 \%$. During an environmental change most significantly declined the influence of Scots pine and common hornbeam from $40 \%$ and from $55 \%$ down to $<0.4 \%$, respectively. While average influence of coniferous trees as well as land improvement deciduous slightly decreased from c. $33.3 \%$ to $21.9 \%$ and from $16.9 \%$ to $13.2 \%$, respectively, the influence of stand-forming deciduous beech and oaks increased moderately. During the period of dominant industrial load, the discrimination of the influence of oak was $32.6 \%$, ash - $29.4 \%$, common hornbeam $55.6 \%$, lime - $16.7 \%$. During the period of a regional environmental change, the discrimination of the influence of oak on soil slightly increased to $34.6 \%$. The discrimination of the influence of ash reached more than $10.5 \%$ and greater influence was also exercised by alder on topsoil. Among deciduous trees, willow reached the most reliable separability of almost $63 \%$ (Tab. 3). Contemporary differences between separability of top- and subsoil horizons indicate to what extend the influence of trees on soil is conditioned by unique soil-forming substrate properties. The influence of coniferous trees is insignificant and conditioned by the bedrock. On the other hand, oak, common hornbeam and maple significantly affected the topsoil horizons. Although the influence of alder and willow on the topsoil was insignificant, a decrease in acid depositions increased it.

\section{Geographically weighted regression}

Decrease in acid deposition induced changes in spatial dependences of soil properties with forest environment. The dependence of the topsoil diversity on acid deposition became insignificant. However, dependence was strengthened between the diversity of topsoil and bedrock, soil associations and trees. Even though the forest environment influence on soil properties has constantly been mutual, their spatial distribution increased correlatively during an environmental change. The spatial relationship, that has became most evident, was between the bedrock and topsoil properties diversity. Forest soil diversity is most affected with decreasing importance - by bedrock, forest tree species composition and soil associations. Dependence between soil properties and bedrock or soil associations are not affected by data inhomogeneities. The relationship between diversities of soil properties and tree species is influenced by autocorrelation decreasing proportionally with acid deposition decline (Tab. 4). Being in a relationship with bedrock diversity or forest tree diversity, soil properties geographically weighted parameters in individual bioregions were either equally proportional or variously proportional. The only parameter that was equally proportional to bedrock and forest trees was $\mathrm{MgO}$ content. The parameters of other soil properties were variously proportional in relations with geodiversity and FTSD. The proportions are inverse in majority of the bioregions. 


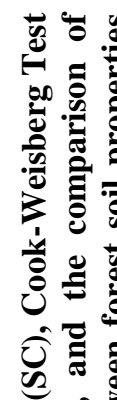

(2)

t)

部究

客

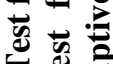

5

2.

总

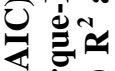

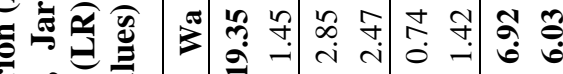

政

政家

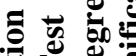

运

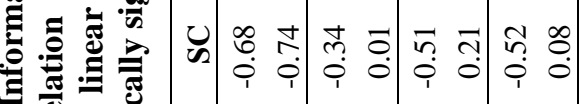

政

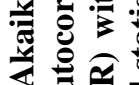

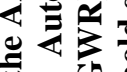

政

on

零要

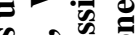

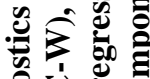

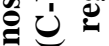

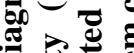

政

한

可

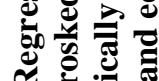

$\approx 5$

$\because \because 2$

踏

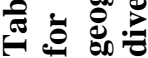

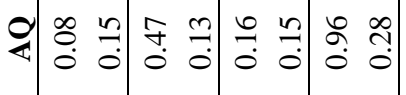

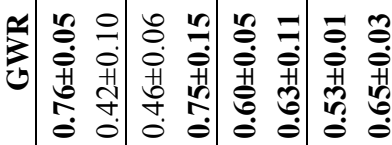

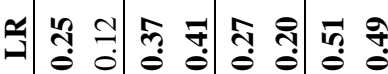

$\infty$

נ)

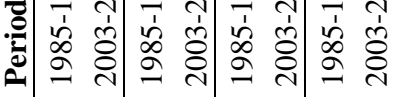

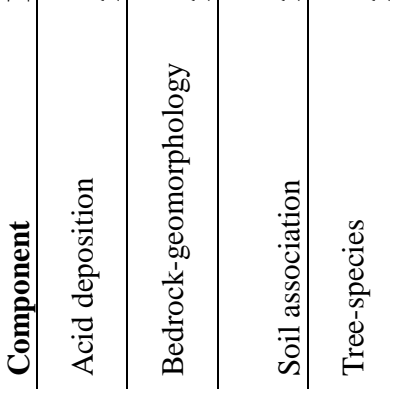

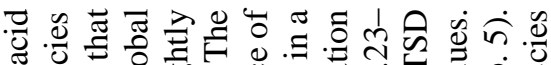

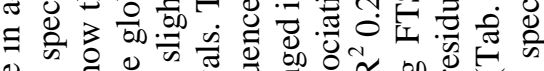
$\otimes$ \& क

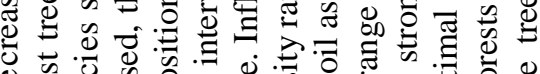

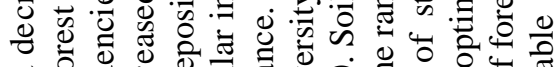

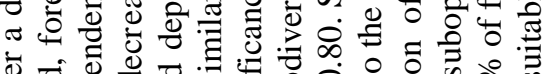
एँ

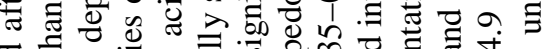
चु

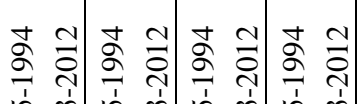

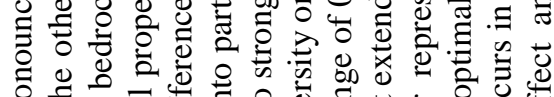

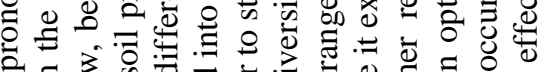
o 0 . 氙出。

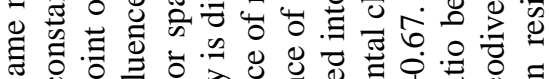
过

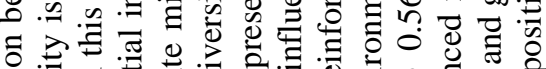

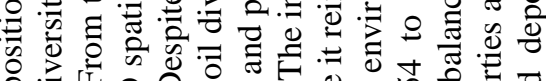

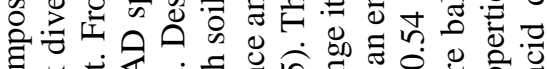

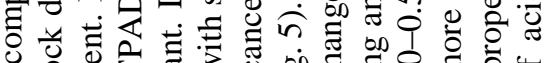

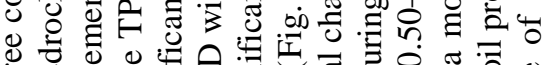

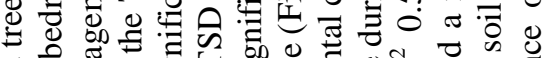

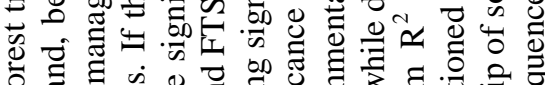

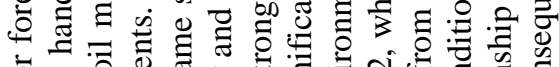
б

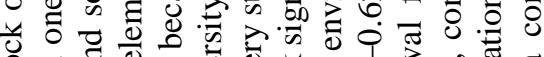
ช

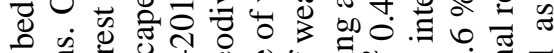

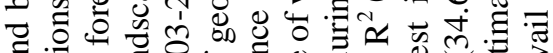

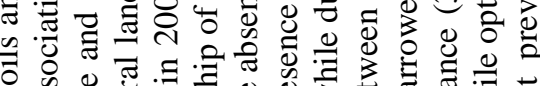

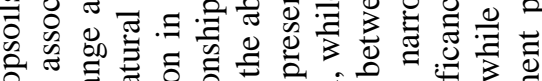

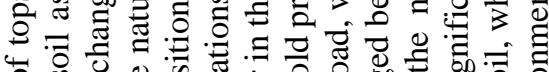
응 0

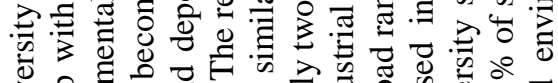
D. ข

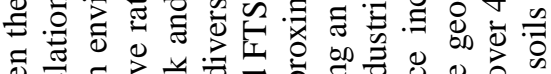
ญ

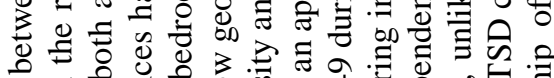

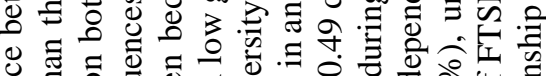

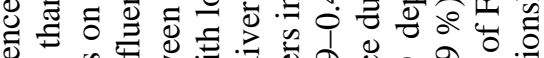

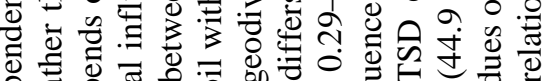

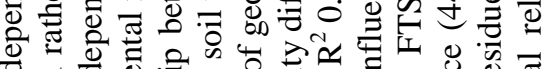

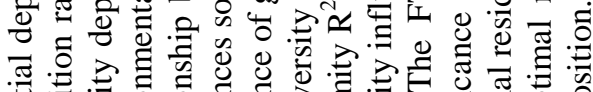

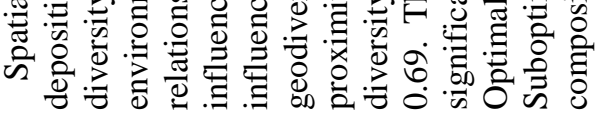


Fig. 5: Shanno-Wienner' indexes of bedrock-geomorphological bodies, forest soil associations and tree-species compositions in biogeographical regions of the Czech Republic and spatial regressions with topsoil diversities during period of environmental change 2003-2012
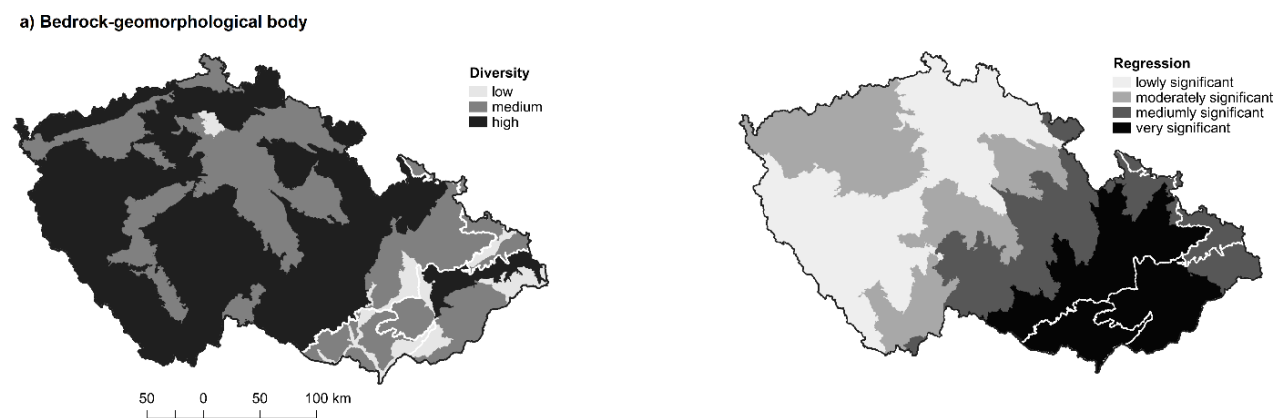

b) Forest soil association
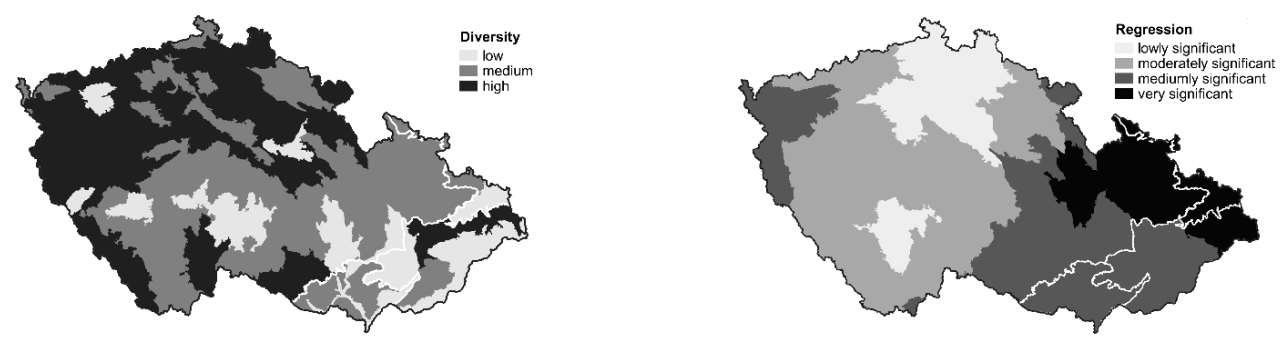

c) Tree-species composition
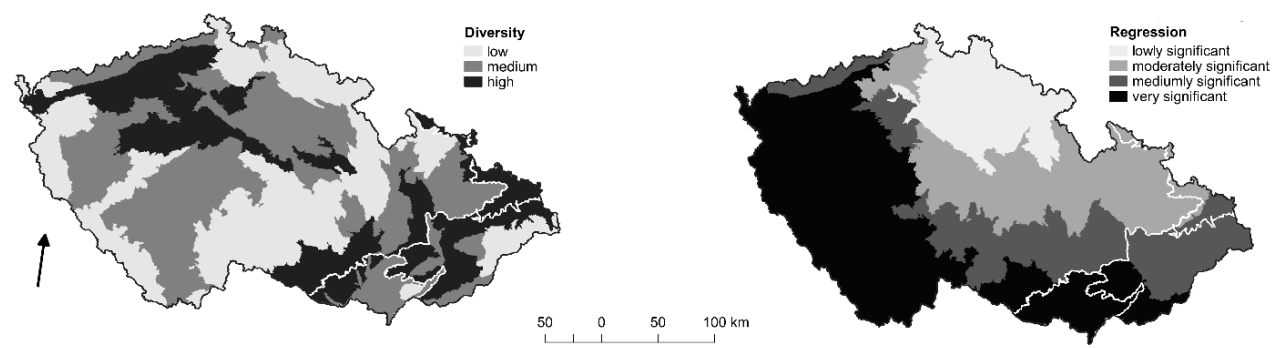

Table 5: Comparison of the value proportion intervals (\%) of spatial dependence proximity $\left(R^{2}\right)$ and residues between geographically weighted regressions (GWR) of geodiversity and forest tree species diversity (FTSD) with soil properties

\begin{tabular}{llrr}
\hline GWR & Interval & Geodiversity & FTSD \\
\hline $\mathrm{R}^{2}$ & slight & 30.84 & 15.89 \\
& moderate & 17.76 & 22.43 \\
& medium & 16.82 & 16.82 \\
& high & 34.58 & 44.86 \\
& very high & 0.00 & 0.00 \\
\hline \multirow{2}{*}{ Residue } & optimum & 44.86 & 46.73 \\
& non-optimum & 55.14 & 53.27 \\
\hline
\end{tabular}


Samec P., Zapletal M., Horáček M.: Forest transformation urgency for topsoil diversity optimization during environmental change

Moderate non-compliance in the occurrence of optimal and suboptimal residues between geographically weighted models of the geodiversity and FTSD relationship caused the occurrence of all potential types from the forest compositional transformation urgency. The dominance of suboptimal residues conditioned the dominance of variously urgent forest transformation needs. Sufficient FTSD in accordance with soil diversity only occurs in $12.9 \%$ of forests. As much as $87.1 \%$ of forests is characterised by suboptimal relationship between tree species diversity and topsoil properties. Mean to high forest transformation urgency is related to $65.9 \%$ of soils. Sufficient FTSD is concentrated in Central Bohemia and Polonian Subprovince. In an isolated manner, it occurs in the bioregions of Sokolov, České Budějovice, Votice, Nová Bystřice, Drahany and Chřiby. Low forest transformation urgency was identified in Český les Mts., Brdy, Blatenská pahorkatina Hills, western part of the Bohemian-Moravian Highland, Eastern-Elbe Plateau and scattered in the Carpathian bioregions of Mikulov, Hodonín, Kojetín, Hostýn and Beskids. Mean forest transformation urgency is most concentrated in Northern Bohemia and Carpathian Foredeep, while high urgency is continuously identified in the areas of eastern foothills of the Bohemian-Moravian Highland up to Eastern Sudetes and the foothills of the Giant Mts. and from the Bohemian Forest to Plzeň pahorkatina Hills and Slavskovský les Forest (Fig. 6).

Fig. 6: The forest transformation urgency in biogeographic regions from overlays between residues of geodiversity and forest tree species

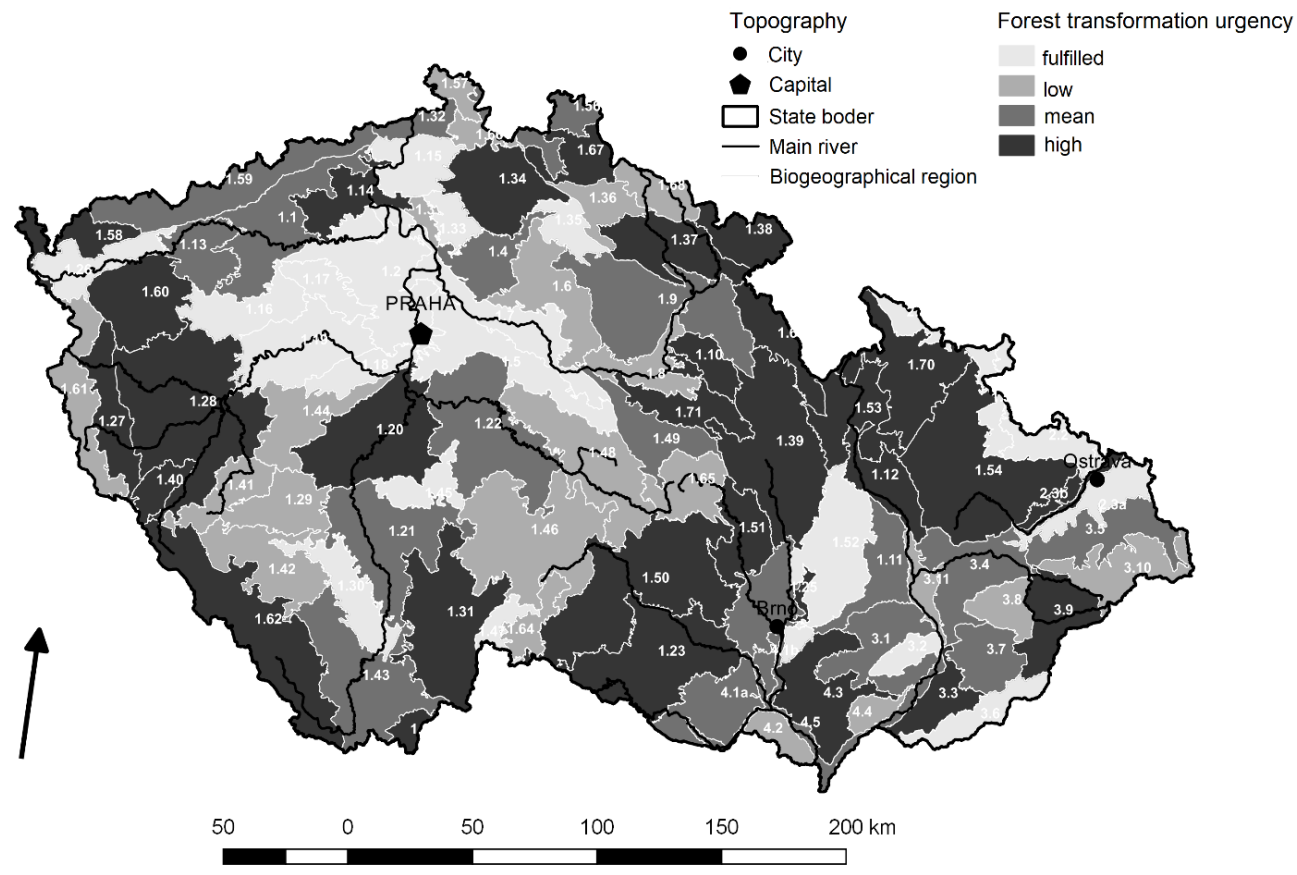

Low FTSD is not related to low soil diversity, but BGMB diversity includes less than $12.6 \%$ of the dispersion at forest tree species proportion with $P<0.001$. The relationship of soil properties and trees is significant starting from the diversity $>1.66$. Sufficient FTSD is in a range of $2.79 \pm 0.46$ at on-average lower geodiversity of $2.06 \pm 0.72$. Homogenised FTSD is indicated by values of $<2.79$, while diversity values of $\geq 2.79$ indicate differentiated 
influence on soil properties. Low FTSD is partially related to on-average higher geodiversity of $2.67 \pm 0.80$ with the total interval of $0.00-4.17$ equal to the total bedrock diversity in bioregions. Higher FTSD is related to on-average lower geodiversity of $2.10 \pm 1.09$ in a narrower interval of 0.01-3.50. Bioregions with sufficient FTSD are characterised by on-average representation of Norway spruce of $<33 \%$, while the European beech or oak reaches $>10 \%$, ash $>2.47 \%$, maple $>1.73 \%$, common hornbeam $>2.1 \%$, and lime or alder $1.9 \%$ (Tab. 6). Proposals of forest composition optimization based on spatially weighted models from soil properties show that topsoil correlating properties indicate relationship with trees in regionally dissimilar proportions. The proportions differ not only among individual properties, but also among bioregions and even among subprovinces. It is only base saturation outside the Hercynian Subprovince and on the other hand the contents of $\mathrm{Al}_{2} \mathrm{O}_{3}$ or $\mathrm{CaO}$ in the Hercynian Subprovince that show average dependence proportions that are equal to geodiversity as well as tree species diversity.

Table 6: Characteristic intervals of ecosystem diversity and the tree proportion in individual forest transformation urgency types

\begin{tabular}{llrrrr}
\hline \multirow{2}{*}{ Level } & Ecodiversity & \multicolumn{3}{c}{ Forest transformation urgency } \\
\cline { 3 - 5 } & & fulfilled & low & mean & high \\
\hline System & Geodiversity & $2.06 \pm 0.72$ & $2.25 \pm 0.85$ & $2.92 \pm 0.83$ & $2.89 \pm 0.86$ \\
$\left(H^{*}\right.$-index $)$ & Soil diversity & $1.93 \pm 0.74$ & $1.87 \pm 0.61$ & $2.23 \pm 0.75$ & $2.11 \pm 0.57$ \\
& FTSD & $2.79 \pm 0.46$ & $1.84 \pm 0.42$ & $2.69 \pm 0.41$ & $2.11 \pm 0.60$ \\
& $R^{2}$ & $0.63 \pm 0.14$ & $0.58 \pm 0.15$ & $0.60 \pm 0.16$ & $0.63 \pm 0.14$ \\
\cline { 2 - 5 } Tree species & Proportion $(\%)$ & 12.91 & 21.24 & 20.58 & 45.28 \\
\hline Picea & P. sylvestris & 32.19 & 65.14 & 42.37 & 57.15 \\
& P. uncinata + mugo & 19.91 & 11.52 & 16.98 & 18.27 \\
& Abies & 0.00 & 0.42 & 0.41 & 0.22 \\
& Larix & 0.64 & 0.99 & 0.77 & 1.27 \\
& Fagus & 6.26 & 2.95 & 5.01 & 3.43 \\
& Quercus & 12.09 & 7.50 & 7.52 & 7.04 \\
& Betula & 13.96 & 4.55 & 11.81 & 4.71 \\
& Fraxinus & 3.05 & 2.05 & 4.44 & 2.43 \\
& Acer & 2.47 & 1.03 & 2.47 & 0.88 \\
& Carpinus & 1.74 & 0.86 & 1.73 & 1.31 \\
& Tilia & 2.87 & 0.42 & 2.09 & 0.90 \\
& Alnus & 2.17 & 0.59 & 1.83 & 0.87 \\
& Populus & 1.98 & 1.75 & 1.82 & 1.38 \\
Salix & 0.53 & 0.17 & 0.56 & 0.09 \\
\hline & & 0.15 & 0.05 & 0.19 & 0.06 \\
\hline
\end{tabular}

\section{DISCUSSION}

\section{General discussion}

Environmental change directly affects the size of spatial differences at forest ecosystem diversity. The diversity of soil environment is connected with the tree species diversity among individual biogeographical regions almost contrarily. Contradictory parameters confirmed local character of ecosystem diversity indication through soil properties 
Samec P., Zapletal M., Horáček M.: Forest transformation urgency for topsoil diversity optimization during environmental change

(Anderson, 2003). Decline in acid deposition increased spatial dependence between soil properties extent and tree composition variety. With the deposition decrease, there was the highest increase in the relationship between forest soil properties and geodiversity, and the relationship with tree species composition increased more than with soil associations. Geodiversity includes the most important divides among various differentiability of soil properties and natural tree dominance (Samec et al., 2018) The deriving of geodiversity from BGMBs divided the forest transformation urgency among variously broken landforms with different forest cover. At the same time, it revealed that the bedrock influences the topsoil properties more than trees and that forest tree composition diversity is not in accordance with landscape diversity. Despite this, spatially weighted forest ecosystem diversity indication modified the assessment on optimization of tree species composition.

Geographical differences in forest ecosystem diversity suggest that spatially weighted modelling fails to correspond with the case studies using global models. Inverse connections between bedrock and forest diversity are in conflict with the analyses of the forest management plan database (cf. Tomášková, 2004). According to Kučera (2016), forest transformation manifested itself in the dominance of vegetation containing land improvement and strengthening trees in compliance with the site. However, the forest mixture character is insufficient for the extension of consistency between the size of geodiversity and tree composition diversity. Geodiversity only correlates with $12.6 \%$ of the dispersion of forest tree diversity and optimal relationship between geo- and FTSD only includes $12.9 \%$ of soils. If case studies indicate that the relationship between forest soils and trees are similar in equal conditions of various forest areas, the spatial model points to the fact that the relationship differs in various areas regardless of the similarity between conditions (cf. Cools et al., 2014; Shi et al., 2015; Zeng et al., 2016). Sufficient FTSD is concentrated in flat forest areas of the Cheb and České Budějovice Basins, Chřiby and Bílé Karpaty Mts. with tree species composition that is similar to that potentially natural (Tomášková, 2004). The occurrence of optimal forest tree species diversity is not connected with the state of contemporary and potentially natural vegetation (PNV) in bioregions with relatively broken landforms. Similarly high forest transformation urgency is related to distinctly unnatural trees only in highland areas of the eastern part of the Bohemian Massif. The dominance of sampled spruce stands influences both the indication of topsoil acidification derived from dimensionality reduction among chemical properties, and spatial autocorrelation derived by means of spatial modelling (Kikkilä et al., 2005).

\section{Discussion of forestry applications}

\section{Modelling of the tree-soil system}

Relations between forest trees and soil are variable and uneven (Aubert et al., 2006). The instability of relationships in TSS was caused by environmental load, decreasing conifer proportion, and fluctuating forest stand structure. The causes of TSS instability either supressed or highlighted the bedrock influence. Reduced environmental load made it possible to classify more than $50 \%$ of the dispersion of soil properties along transits between forest sites. Prevailing conifer silviculture limited the extent of humus properties division, which was indicated by dominant soil properties separability in spruce stands.

The homogenous forest structure decreased indication significance of relations with soil environment (Tinya et al., 2019). More than $87 \%$ of forest stands in the territory of the Czech Republic is characterised by a simplified structure. Almost $66 \%$ of forests show criteria of non-compliance with geodiversity for mean to high transformation urgency. However, simplification of tree species composition only affected some components of soil diversity. It is not connected with the soil association diversity but it contributed to the 
topsoil chemical diversity decline. The insignificance of the connections between homogenous forest stands and soil diversity signals that monocoenoses do not importantly increase the topsoil diversity (Ali, 2019). The proposals of site-corresponding forest tree composition can hardly make TSS more effective globally, but it can support its function in vulnerable sites within affected bioregions.

Case studies of TSS functions focused on forest transformation are divided both into the characteristics of sites for natural regeneration of individual tree species and into the monitoring of the soil improvement (Ponge et al., 1998). Uneven spatial dependences suggest improvement of the TSS indication through transition from global models to the spatial models. Spatial models preserving heteroscedastic residues capture non-repeatability of the variance in soil properties among the compared areas in contrast to kriging depended on autocorrelation (Ĺímanová et al., 2020). Although the trees control humus $\mathrm{C} / \mathrm{N}$, the contents of mineral nutrients are directly proportional to bedrock (Podrázský et al., 2009). A greater emphasis on the soil properties segmentation along the BGMB transitions than in variously diverse forest stands indicates that bedrock is decisive for soil diversity. On the other hand, biodiversity increases soil diversity as it develops thanks to organisms inducing nutrient uptake from bedrock (Augusto et al., 2000; Anderson, 2003; Oulehle et al., 2011). Although, the cultivation of homogenous stand prevents tree natural selection on variously fertile soils, BGMBs following more distinctive growth condition borders affect the functions within the tree-soil system more than prevailing conifer stands.

Differentially fertile soils separate natural regeneration of nutrient-demanding and undemanding tree species. Marginal sites consist of unrelated poorest or, on the other hand, most fertile soils. While specialised stenoec tree species grow together with unspecialised euryvalent tree species on the poorest soils, the most fertile soils are predominantly occupied by demanding tree species. Marginal soil fertility provides site for various azonal communities of specialised species (Rejšek \& Samec, 2004). Pendunculate oak (O. robur), sessile oak ( $Q$. petraea), European ash ( $F$. excelsior), silver birch (B. pendula) or alder (Alnus sp.) prefer mesophilic sites including Retisols, Cambisols, Podzols and Gleysols. Retisols are equally colonised by birch, ash, and alder. Cambisols are preferably occupied by silver birch (up to $57 \%$ ) and oak (over $17 \%$ ). Podzols are most often silver birch (33\%) or white birch (47 \%) (Rejšek et al., 2010). Even though Gleysols differ from mesophilic soils in $\mathrm{C}_{\text {org }}$ a $\mathrm{N}_{\mathrm{t}}$ dynamics in reductomorphic conditions, the contents of nutrients are homologous, so they are occupied by common alder (50\%) and silver birch (30\%). The contents of $\mathrm{Ca}^{2+}+\mathrm{Mg}^{2+}, \mathrm{Zn}$, and BS separate the presence of silver birch or white birch on Podzols. Soil pH, on the contrary, separates the regeneration of pedunculate oak, birch or alder on Retisols and Cambisols. Retisols and Cambisols support the growth of elm and sycamore, but the growth of beech or Norway maple is independent on the soil group (Modrý et al., 2004). The occurrence of white birch is most concentrated on Histosols and in a transitional area towards Podzols and Gleysols with the lowest $\mathrm{pH}$ values, where other deciduous trees are unable to grow. While the white birch is a stenoec species, the silver birch is able to compete with oaks, willows and aspens in loaded conditions, but the its humus properties rather resemble coniferous than deciduous trees on mesophilic soils (Vacek et al., 2013; Cools et al., 2014; Tinya et al., 2019).

\section{Forest transformation modelling}

Permanent success at the optimization of forest tree species composition is conditioned by the soil acidification impact elimination. The optimization of forest composition in the territory of the Czech Republic is concentrated on the spruce or pine monoculture transformation. The difference between the spruce and pine monoculture transformation 
Samec P., Zapletal M., Horáček M.: Forest transformation urgency for topsoil diversity optimization during environmental change

consists in the fact that pine cultures are cultivated within the height range of their natural occurrence, while spruce cultures were rather established outside the natural spruce dominance sites (Šindelár̆, 1995). As a result of forest monoculture cultivation, low forest tree species diversity is identified in a wide range of bedrock diversity. However, overlays between geodiversity and FTSD distinguished areas of naturally higher ecosystem diversity in lower altitudes from areas of lower ecosystem diversity in higher altitudes. Exploratory TSS analysis consequetly suggested the forest transformation limitation within individual bioregions only to sites with inconvenient soil environment.

While spruce has become economically the most important forest tree in Central Europe, Scots pine is mainly cultivated on less fertile sites. Economic significance of spruce consists not only in its ability to fully overgrow treeless areas, but also in its occurrence in the developmental centre with many refuges scattered in reproductively favourable sites (Ďurský et al., 2006). Spruce refuges are stable mixtures mainly with beech, fir or maple, while natural pine forests permanently exist in extraordinarily unfavourable sites. Outside extremely unfavourable sites, pine can hardly sustain the competition of more demanding tree species (Neuhäuslová et al., 1998). Still, spruce and pine monocultures similarly suffer from low mechanical resistance, pest gradations and soil acidification (Pretzsch et al., 2014). The pine monoculture transformation appears to be more complicated with regard to low competition. In unnatural sites, pine is excluded from potential natural vegetation; on the contrary, natural pine sites are hardly infiltrated by deciduous trees. Pine cultivation on transient sites appears to be sustainable in the mixture of oak, birch, larch, spruce and more demanding deciduous trees (Šindelář et al., 2007).

Transformations of spruce monocultures are necessary measures against the impact of drought or industrial pollution (Schröder et al., 2015). Due to the spruce ability to grow within a stable tree species mixture, total spruce elimination from unnatural sites is economically very problematic (cf. Kuuluvainen, 2002; Tuovinen et al., 2013; Pretzsch et al., 2014). The spruce monoculture transformations are planned as a compromise to maintain all forest functions. In compliance with compromise approaches maintaining economic-ecological-social management frameworks, spatial modelling indicated below-average spruce proportion as optimal. Forest transformation urgency was however differently typified using the ratio of total geodiversity over biodiversity, which disregards criteria interchangeability.

The connection between a demanding forest tree species decline and sites damaged by acidification was suggested by non-compliance between a decrease in average separability of soil properties influenced by trees and an increase in the relationship with both the compared ecosystem diversity components. At the same time, a significantly wider range between geodiversity and soil properties rather than biodiversity indicated contemporary occurrence of soils not only delimited by BGMBs, but also soils independent on rock proportion variety. An increase in the separability of oak, willow, alder, maple, larch or (Swiss) mountain pine growing along marginal ecological gradients along with an increase in the dependence between soils and bedrock confirmed the concentration of natural forests on azonal sites. Azonal oak, willow and alder sites cover floodplains with low geodiversity and naturally higher biodiversity (Klimo et al., 2008). The overlap of lower geodiversity and higher biodiversity distinguished the restoration of natural forests mainly in hilly bioregions. At the same time, the largest floodplains include conditions from fulfilled urgency in the regions of Elbe and Odra Basins to mean transformation urgency in Outer Carpathian depressions.

Slight increase in the Norway spruce separability followed by its proportion decrease corresponds with the stable occurrence preservation only in the conditions of natural dominance (Vacek et al., 2013; Tuovinen et al., 2013; Schröder et al., 2015). On the 
contrary, the increasing separability of mountain pine indicated optimal forest composition in high-mountainous zones of the Giant Mts. with prevailing slight transformation urgency (cf. Vacek et al., 2007). However, pine sites on the Bohemian Forest plateau with prevailing high transformation urgency provide optimum conditions for silviculture of Swiss mountain pine (Kuuluvainen, 2002). The trend of increasing dependencies between the forest soil properties and ecosystem diversity during an environmental change only seems to be sustainable when the load is decreased and natural forests restored.

\section{CONCLUSION}

Relations between the forest tree species and topsoil chemical properties diversities became tighter during a recent environmental change in connection with an acid deposition decrease. An increase in spatial dependencies between forest soil properties and the ecosystem diversity confirms the importance of site differentiation in forest transformation.

An acid deposition decrease is a starting process allowing development of relations between forest trees and soils. The development of the tree-soil system consists in the differentiation between biogeographic subprovinces and increased differences in soil properties between monocultures and structured forest stands. The acid deposition decrease accentuated regional differences in topsoil $\mathrm{pH}$, base saturation and carbon, $\mathrm{CaO}, \mathrm{MgO}$ and $\mathrm{P}_{2} \mathrm{O}_{5}$ contents, while regional differences in CEC and the $\mathrm{Al}_{2} \mathrm{O}_{3}$ content decreased. Regional differences increased on the borderline among bedrock-geomorphological bodies more significantly than between the stands with various tree species composition. Average differentiation of the influence of conifers or nutrient-demanding deciduous trees on soil decreased, yet the influence of European beech, maple, oak and willow increased. Even though the highest decrease was observed in the influence of Scots pine and common hornbeam, the differences between influencing topsoil and bedrock were the highest in connection with the oak, hornbeam, maple and willow stands. Non-compliances between geodiversity, soil diversity and tree species diversity pointed to uneven extension of the forest transformation urgency.

\section{ACKNOWLEDGEMENT}

The study was supported by the projects UIA03-123 CLAIRO of the European Commission, LM2018123 CzeCOS of the Ministry of Education, Youth and Sports of the Czech Republic and University of Ostrava project SGS02/PřF/2019-2020.

\section{REFERENCES}

Ali, A. (2019). Forest stand structure and functioning: Current knowledge and future challenges. Forest Ecology \& Management 98: 665-677.

Anderson, T.-H. (2003). Microbial eco-physiological indicators to asses soil quality. Agriculture, Ecosystems \& Environment 98: 285-293.

Aubert, M., Alard, D., Bureau, F. (2003). Diversity of plant assemblages in managed temperate forests: a case study in Normandy (France). Forest Ecology \& Management 175: 321-337.

Augusto, L., Turpault, M.-P., Ranger, J. (2000). Impact of forest tree species on feldspar weathering rates. Geoderma 96: 215-237. 
Samec P., Zapletal M., Horáček M.: Forest transformation urgency for topsoil diversity optimization during environmental change

Bellard, C., Bertelsmeier, C., Leadley, P., Thusller, W., Courchamp, F. (2012). Impacts of climate change on the future of biodiversity. Ecology Letters 15: 365-377.

Blakemore, L. C., Metson, A. J. (1960). Micro-Determination of Cation-Exchange Capacity and Total Exchangeable Bases. Soil Science 89: 202-208.

Bremner, J.M. (1996). Nitrogen-Total. In: Sparks D.L., Page A.L., Helmke P.A., Loeppert R.H., Soltanpour P.N., Tabatabai M.A., Johnston C.T., Sumner M.E. (eds.), Methods of Soil Analysis. Part 3. Chemical Methods (pp. 1085-1122). Soil Science Society of America, American Society of Agronomy, Madison.

Buckee, G.K. (1994). Determination of total nitrogen in barley, malt and beer by Kjeldahl procedures and the Dumas combustion method - Collaborative trial. Journal of the Institute of Brewing 100: 57-64.

Büntgen, U., Tegel, W., Nicolussi, K., McCormick, M., Frank, D., Trouet, V., Kaplan, J.O., Herzig, F., Heussner, K.-U., Wanner, H., Luterbacher, J., Esper, J. (2011). 2500 Years of European Climate Variability and Human Susceptibility. Science 331: 578-582.

Chapin, III F.S., Zavaleta, E.S., Eviner, V.T., Naylor, R.L., Vitousek, P.M., Reynolds, H.L., Hooper, D.U., Lavorel, S., Sala, O.E., Hobbie, S.E., Mack, M.C., Díaz, S. (2000). Consequences of changing biodiversity. Nature 405: 234-242.

Chisholm, R.A., Muller-Landau, H.C., Rahman, K.A., Bebber, D.P., Bin, Y., Bohlman, S.A., Bourg, N.A., Brinks, J., Bunyavejchewin, S., Butt N., Cao, H., Cao, M., Cárdenas, D., Chang, L.-W., Chiang, J.-M., Chuyong, G., Condit, R., Dattaraja, H.S., Davies, S., Duque, A., Fletcher, Ch., Gunatilleke, N., Gunatilleke, S., Hao, Z., Harrison, R.D., Howe, R., Hsieh, Ch.-F., Hubbell, S.P., Itoh, A., Kenfack, D., Kiratiprayoon, S., Larson, A.J., Lian, J., Lin, D., Liu, H., Lutz, J.A., Ma, K., Malhi, Y., McMahon, S., McShea, W., Meegaskumbura, M., Razman, S.M., Morecroft, M.D., Nytch, Ch.J., Oliveira, A., Parker, G.G., Pulla, S., PunchiManage, R., Romero-Saltos, H., Sang, W., Schurman, J., Su, S.-H., Sukumar, R., Sun, I-F., Suresh, H.S., Tan, S., Thomas, D., Thomas, S., Thompson, J., Valencia, R., Wolf, A., Yap, S., Ye, W., Yuan, Z., Zimmerman, J.K. (2013). Scale-dependent relationships between tree species richness and ecosystem function in forests. Journal of Ecology 101: 1214-1224.

Cools, N., Vesterdal, L., De Vos, B., Vanguelova, E., Hansen, K. (2014). Tree species is the major factor explaining $\mathrm{C}: \mathrm{N}$ ratios in European forest soils. Forest Ecology \& Management 311: 3-16.

Culek, M. (2007). Biogeographical division of the Czech Republic. In: Dreslerová J. (ed.), Ekologie krajiny (pp. 50-57). Lesnická práce, Kostelec nad Černými lesy.

Culek, M., Grulich, V. (2009). Biogeographical division. 1:500 000. In: Hrčianová, T., Mackovčin, P. Zvara, I. (eds.), Landscape Atlas of the Czech Republic (pp. 150-151). Prague: Ministry of Environment, The Silva Tarouca Research Institute for Landscape and Ornamental Gardering.

De Deyn, G.B., Cornelissen, J.H.C., Bardgett, R.D. (2008). Plant functional traits and soil carbon sequestration in contrasting biomes. Ecology Letters 11: 516-531.

Durský, J., Škvarenina, J., Mindáš, J., Miková, A. (2006). Regional analysis of climate change impact on Norway spruce (Picea abies L. Karst) growth in Slovak mountain forests. Journal of Forest Science 51: 306-315.

Erisman, J. W., Vermeulen, A., Hensen, A., Flechard, C., Dämmgen, U., Fowler, D., Sutton, M., Grünhage, L., Tuovinen, J.-P. (2005). Monitoring and modelling of biosphere/atmosphere exchange of gases and aerosols in Europe. Environmental Pollution 
133: 403-413.

Faddy, M.J., Smith, D.M. (2011). Analysis of count data with covariate dependence in both mean and variance. Journal of Applied Statistics 38: 2683-2694.

Fotheringham, A.S., Brunsdon, C., Charlton, M. (2002). Geographically Weighted Regression: the Analysis of Spatially Varying relationships. John Wiley \& Sons, Chichester. Galloway, J.N., Townsend, A.R., Erisman, J.W., Bekunda, M., Cai, Z., Freney, J.R., Martinelli, L.A., Seitzinger, S.P., Sutton, M.A. (2008). Transformation of the Nitrogen Cycle: Recent Trends, Questions, and Potential Solutions. Science 320: 889-892.

Gill, R.M.A., Beardall, V. (2001). The impact of deer on woodlands: the effects of browsing and seed dispersal on vegetation structure and composition. Forestry 74: 209-2018.

Gollini, I., Lu B., Charlton, M., Brundson, C., Harris, P. (2015). GWmodel: an R Package for Exploring Spatial Heterogeneity using Geographically Weighted Models. Journal of Statistical Software 63: 1-52.

Guo, Y., Gong, P., Amundson, R. (2003). Pedodiversity in the United States of America. Geoderma 117: 99-115.

Hopkins, F., Gonzalez-Meler, M.A., Flower, C.F., Lynch, D.J., Czimczik, C., Tang, J., Subke, J.-A. (2013). Ecosystem-level controls on root-rhizosphere respiration. New Phytologist 199: 339-351.

Houba, V.G.J., van der Lee, J.J., Novozamsky, I., Walinga, I. (1989). Soil Analysis Procedures. Soil and Plant Analysis, Part 5. Wageningen Agricultural University.

Houba, V.G.J., Chardon, W.J., Roelse, K. (1993). Influence of Grinding of Soil on Apparent Chemical Composition. Communication in Soil Science and Plant Analysis, 24: 1591-1602.

Ibañez, J.J., Feoli, E. (2013). Global relationships of pedodiversity and biodiversity. Vadose Zone Journal 12: vzj2012.0186.

Kennedy, A.C., Smith, K.L. (1998). Soil microbial diversity and the sustainability of agricultural soils. Plant and Soil 170: 75-86.

Kikkilä, O., Kitunen, V., Smolander, A. (2005). Degradability of dissolved soil organic carbon and nitrogen in relation to tree species. FEMS Microbiology Ecology 53: 33-40.

Klimo, E., Hager, H., Matić, S., Anić, I., Kulhavý, J. (eds.) (2008). Floodplain forests of the temperate zone of Europe. Lesnická práce, Kostelec nad Černými lesy.

Kooch, Y., Jalilvand, H., Bahmanyar, M.A., Pormajidian, M.R. (2008). The Use of Principal Component Analysis in Studying Physical, Chemical and Biological Soil Properties in Southern Caspian Forests (North of Iran). Pakistan Journal of Biological Sciences 11: 366372.

Kučera, M. (2016). Czech Republic. In: Vidal, C., Alberdi, I., Hernández, L., Redmond, J. (eds.), National Forest Inventories: Assessment of Wood Availability and Use (pp. 307-326). Springer International Publishing Switzerland, Cham.

Kuuluvainen, T. (2002). Natural variability of forests as a reference for restoring and managing biological diversity in boreal Fennoscandinavia. Silva Fennica 36: 97-125.

Langan, S.J., Wilson, M.J. (1994). Critical loads of acid deposition on Scottish soils. Water, Air, and Soil Pollution 75: 177-191.

Legout, A., Nys, C., Picard, J.-F., Turpault, M.-P., Dambrine, E. (2009). Effects of storm Lothar (1999) on the chemical composition of soil solutions and on herbaceous cover, humus and soils (Fougères, France). Forest Ecology \& Management 257: 800-811. 
Samec P., Zapletal M., Horáček M.: Forest transformation urgency for topsoil diversity optimization during environmental change

Luterbacher, J., Dietrich, D., Xoplaki, E., Grosjean, M., Wanner, H. (2004). European Seasonal and Annual Temperature Variability Trends and Extremes Since 1500. Science 303: 1499-1503.

Mauer, O., Rozmánek, M., Houšková, K. (2018). Drought spells and their impact on the growth of young plantations established with the containerized planting stock. Acta Universitatis agriculturae et silviculturae Mendelianae Brunensis 66: 89-99.

Meloun, M., Militký, J., Hill, M., Brereton, R.G. (2002). Crucial problems in regression modelling and their solutions. Analyst 127: 433-450.

Modrý, M., Hubený, D., Rejšek, K. (2004). Differential response of naturally regenerated European tree species to soil type and light availability. Forest Ecology \& Management 188: 185-195.

Neuhäuslová, Z., Blažková, D., Grulich, V., Husová, M., Chytrý, M., Jeník, J., Jirásek, J., Kolbek, J., Kropáč, Z., Ložek, V., Moravec, J., Prach, K., Rybníček, K., Rybníčková, E., Sádlo, J. (1998). Map of Potential Natural Vegetation of the Czech Republic /Text part/. Academia, Praha.

Oulehle, F., Evans, C.D., Hofmeister, J., Krejčí, R., Tahovská, K., Persson, T., Cudlín, P., Hruška, J. (2011). Major changes in forest carbon and nitrogen cycling caused by declining sulphur deposition. Global Change Biology 17: 3115-3129.

Phillips, J.D., Marion, D.A. (2004). Pedological memory in forest soil development. Forest Ecology \& Management 188: 363-380.

Podrázský, V., Remeš, J., Hart, V., Moser, W.K. (2009). Production and humus form development in forest stands established on agricultural lands - Kostelec nad Černými lesy region. Journal of Forest Science 55: 299-305.

Ponge, J.-F., André, J., Zackrisson, O., Bernier, N., Nilsson, M.-C., Gollet, C. (1998). The forest regeneration puzzle. Bioscience 48: 523-530.

Ponge, J.-F., Chevalier, R. (2006). Humus Index as an indicator of forest stand and soil properties. Forest Ecology \& Management 233: 165-175.

Pretzsch, H., Biber, P., Schütze, G., Uhl, E., Rötzer, T. (2014). Forest stand growth dynamics in Central Europe have accelerated since 1870. Nature Communications 5: \#4967.

Rejšek, K., Samec, P. (2004). Pedogenesis variability effects in relationship to natural tree composition on selected forest sites. In: Rohošková, M. (ed.): Pedologické dny 2004 (pp. 6364). Pedodiverzita. ČZU v Praze.

Rejšek, K., Haveraaen, O., Sandnes, A., Somerlíková, K. (2010). Soil characteristics under selected broadleaved tree species in East Norway. Journal of Forest Science 56: 295-306.

Ř́manová, V., Menafoglio, A., Pini, A., Pechanec, V., Fišerová, E. (2020). A permutation approach to the analysis of spatiotemporal geochemical data in the presence of heteroscedasticity. Environmetrics 31: e2611.

Samec, P., Rychtecká, P., Tuček, P., Bojko, J., Zapletal, M., Cudlín, P. (2016). A static model of abiotic predictors and forest ecosystem receptor designed using dimensionality reduction and regression analysis. Baltic Forestry 22: 259-274.

Samec, P., Voženílek, V., Vondráková, A., Macků, J. (2018). Diversity of forest soils and bedrock in soil regions of the Central-European Highlands (Czech Republic). Catena 160: 95-102.

Sedláček, J., Janderková, J., Šefrna, L. (2009) Soil associations. 1:500 000. In: Hrčianová, T., 
Mackovčin, P. Zvara, I. (eds.), Landscape Atlas of the Czech Republic (pp. 134-135), Prague: Ministry of Environment, The Silva Tarouca Research Institute for Landscape and Ornamental Gardering.

Schad, P., van Huysteen, C., Michéli, E., Vargas, R. (eds.) (2014). World Reference Base for Soil Resources 2014. International soil classification system for naming soils and creating legends for soil maps. World Soil Resources Reports No. 106. FAO, Rome.

Schröder, W., Nickel, S., Jenssen, M., Riediger, J. (2015). Methodology to assess and map the potential development of forest ecosystems exposed to climate change and atmospheric nitrogen deposition: A pilot study in Germany. Science of the Total Environment 521-522: $108-122$.

Seppälä, R., Buck, A., Katila, P. (2009). Adaptation of Forests and People to Climate Change - A Global Assessment Report. IUFRO, Vienna - Helsinki.

Shi, Z., Ji, W., Viscarra, Rossel, R.A., Chen, S., Zhou, Y. (2015). Prediction of soil organic matter using a spatially constrained local partial least squares regression and the Chinese vis-NIR spectral library. European Journal of Soil Science 66: 679-687.

Stępień, M., Samborski, S., Gozdowski, D., Dobers, E.S., Chormańaki, J., Szatyłowicz, J. (2015). Assessment of soil texture class on agricultural fields using ECa, Amber NDVI, and topographic properties. Journal of Plant Nutrition and Soil Science 178: 523-536.

Šindeláŕ, J. (1995). A preliminary report on autochthonous species composition of forests in the territory of the Czech Republic. Lesnictvi-Forestry 41: 293-299.

Šindeláŕ, J., Frýdl, J., Novotný, P. (2007). Towards a forest stands species composition in consideration of soil-improving and reinforcement forest tree species. Reports of Forestry Research 52: 160-165.

Tinya, F., Márialigeti, S. Bidló, A., Ódor, P. (2019). Environmental drivers of the forest regeneration in temperate mixed forests. Forest Ecology \& Management 433: 720-728.

Tomášková, I. (2004). Evaluation of changes in the tree species composition of Czech forests. Journal of Forest Science 50: 31-37.

Tuovinen, J.-P., Hakola, H., Karlsson, P.E., Simpson, D. (2013). Air Pollution Risks to Northern European Forests in a Changing Climate. In: Matyssek, R., Clarke, N., Cudlín, P., Mikkelsen, T.N., Tuovinen, J.-P., Wieser, G., Paoletti, E. (eds.), Climate Change, Air Pollution and Global Challenges: Understanding and Perspectives from Forest Research (pp. 77-99). Developments in Environmental Science 13.

Vacek, S., Bílek, L., Schwarz, O., Hejcmanová, P., Mikeska, M. (2013). Effect of Air Pollution on the Health Status of Spruce Stands. A Case Study in the Krkonoše Mountains, Czech Republic. Mountain Research and Development 33: 40-50.

Vacek, S., Matějka, K., Simon, J., Malík, V., Schwarz, O., Podrázský, V., Minx, T., Tesař, V., Anděl, P., Jankovský, L., Mikeska, M. (2007). Healt status and dynamics of forest ecosystems under air pollution stress in the Giant Mts. Folia Forestalia Bohemica 4: 1-216.

Valtera, M., Šamonil, P., Boublík, K. (2013). Soil variability in naturally disturbed Norway spruce forests in the Carpathians: bridging spatial scales. Forest Ecology \& Management 310: 134-146.

Vanmechelen, L., Groenemans, R., Van Ranst, E. (1997). Forest Soil Condition in Europe. Results of a Large-Scale Soil Survey. EC-UN/ECE, Brussels - Geneva.

Whittaker, R.J., Willis, K.J., Field, R. (2001). Scale and species richness: towards a general hierarchical theory of species diversity. Journal of Biogeography 28: 453-470. 
Samec P., Zapletal M., Horáček M.: Forest transformation urgency for topsoil diversity optimization during environmental change

White, R.E. (1987). Introduction to the Principles and Practice of Soil Science. Blackwell Scientific Publications, Oxford.

Zapletal, M. (2006). Atmospheric deposition of nitrogen and sulphur in relation to critical loads of nitrogen and acidity in the Czech Republic. Journal of Forest Science 52: 92-100.

Zar, J.H. (1994). Biostatistical Analysis. Prentice-Hall Int., New Jersey.

Zeng, C., Yang, L., Zhu, A.-X., Rossiter, D.G., Liu, J., Liu, J., Qin, C., Wang, D. (2016). Mapping soil organic matter concentration at different scales using a mixed geographically weighted regression method. Geoderma 281: 69-82. 